\title{
The adolescent experience in-depth: Using data to identify and reach the most vulnerable young people-Guinea 2005
}

Population Council

Follow this and additional works at: https://knowledgecommons.popcouncil.org/departments_sbsr-pgy

Part of the Demography, Population, and Ecology Commons, Family, Life Course, and Society Commons, Inequality and Stratification Commons, and the International Public Health Commons How does access to this work benefit you? Let us know!

\section{Recommended Citation}

"The adolescent experience in-depth: Using data to identify and reach the most vulnerable young people-Guinea 2005." New York: Population Council, 2009. 


\section{THE ADOLESCENT EXPERIENCE IN-DEPTH: USING DATA TO IDENTIFY AND REACH THE MOST VULNERABLE YOUNG PEOPLE}

Guinea 2005

Data, Tables, Graphs and Maps Based on the Demographic and Health Surveys 


\section{Population Council}

One Dag Hammarskjold Plaza

New York, New York 10017

Telephone: 001 212-339-0500

Fax: 001 212-755-6052

E-mail: pubinfo@popcouncil.org

www.popcouncil.org

The Population Council-an international, nonprofit, nongovernmental organization-conducts research worldwide to improve policies, programs, and products in three areas: HIV and AIDS; poverty, gender, and youth; and reproductive health. Established in 1952, the Council is governed by an international board of trustees. Its New York headquarters supports a global network of regional and country offices.

Copyright (C) 2009 by The Population Council, Inc.

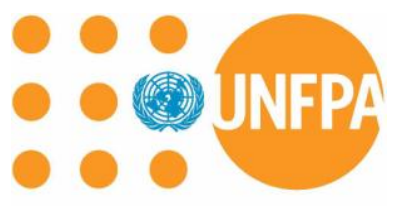

\section{E 42nd St \# 21}

New York, NY 10017

Telephone: 001 212-885-2640

www.unfpa.org

UNFPA, the United Nations Population Fund, is an international development agency that promotes the right of every woman, man and child to enjoy a life of health and equal opportunity. UNFPA supports countries in using population data for policies and programmes to reduce poverty and to ensure that every pregnancy is wanted, every birth is safe, every young person is free of HIV and AIDS, and every girl and woman is treated with dignity and respect.

Any part of this report may be copied or adapted to meet local needs without permission from the Population Council or UNFPA, provided that the parts copied are distributed free or at no cost (not for profit) and that the source is identified. Citation should take the following form: 
"The Adolescent Experience In-Depth: Using Data to Identify and Reach the Most Vulnerable Young People: Guinea 2005." New York: Population Council, 2009.

Any commercial reproduction requires prior permission from the Population Council. The Population Council would appreciate receiving a copy of any materials in which the text is used. 


\section{Table of Contents}

\section{I - Foreword}

II - Technical Notes

III - Investments in Adolescents as a Strategy for Achieving the Millennium Development Goals

IV - Summary of DHS Data on Adolescents

Sections

A - Mapping the Vast Diversity among Adolescents

Population Distribution

Parental Residence in Household $\quad 14$

Parental Survival $\quad 16$

School Enrollment among 10-14 Year Olds $\quad 18$

School Enrollment among 15-19 Year Olds $\quad 19$

Marital Status among Females $\quad 21$

B -Key Transitions among Very Young Adolescents that Lead to Disadvantage 23

Adolescents Not in School and Not Living with Parents $\quad 24$

Females Not in School and Not Living with Parents (map) 26

School Enrollment among 10-17 Year Olds $\quad 27$

Non-Enrollment among School-Age Children $\quad 28$

Females (7-19 year olds) Not in School (map) 29

$\begin{array}{ll}\text { Illiteracy among Females } & 30\end{array}$

Illiteracy among Females (map) $\quad 31$

Illiteracy and Marriage before Age 15

School Enrollment, by Marital and Childbearing Status 34

C - Context of Sexual Activity: Child Marriage, Gender Norms and Reproductive Health 35

Age at First Marriage or Union among Females $\quad 36$

$\begin{array}{ll}\text { Child Marriage among Females (map) } & 37\end{array}$

Pregnancy and Childbearing 38

Sexual Activity among 15-19 Year Old Females $\quad 40$

Sexual Initiation among 20-24 Year Old Females 41

Non-Consensual Sex $\quad 42$

Age Difference between Partners at First Sex $\quad 43$

Age Difference between Current Partners $\quad 44$

Percent Who Find Domestic Violence Acceptable under Any Circumstance $\quad 45$

Percent Who Find Domestic Violence Acceptable under Certain Circumstances 46

$\begin{array}{ll}\text { HIV Testing } & 47\end{array}$

Knowledge of HIV Prevention Methods $\quad 48$

Female Attitudes toward Male Condom Use $\quad 50$

Condom Use $\quad 51$

Contraceptive Use $\quad 52$

Antenatal Care $\quad 53$

Delivery Assistance $\quad 54$

$\begin{array}{lr}\text { V - Concluding Remarks } & 56\end{array}$ 


\section{I- Foreword}

The purpose of the Fact Book series, which draws principally on data from the Demographic and Health Surveys (DHS), is to provide decision makers at all levels - from governments, nongovernmental organizations (NGOs), and advocacy groups - with data on the situation of adolescent girls and boys and young women. The age range covered is 10-24. The data are presented in graphs, tables, and maps (wherever possible), providing multiple formats to make the information accessible to a range of audiences.

Section II offers brief technical notes specific to each country outlining data sources and sample sizes plus any cautions regarding use of the data (such as small sample sizes, issues surrounding the sampling frame, or level of representativeness of the analyses).

Section III provides an overview of the Millennium Development Goals (MDGs) and offers support to those seeking to make the links between appropriate investments in young people and the achievement of the MDGs, particularly in the context of the Poverty Reduction Strategies (PRS) and youth reproductive health and development agendas.

Section IV provides selective summaries of key data for adolescents aged 10-24 and organizes the tables, graphs, and maps into three broad themes meant to assist the reader in exploring the following: the diversity of adolescents; important transitions that take place in early adolescence and adolescents' vulnerability around puberty; and the context of sexual activity, pregnancy, and childbearing.

Section IV-A provides an overview of information on the diversity of adolescents aged 10-24 living in the country, highlighting differences by age, gender, living arrangements, schooling and marital status, and current residence (urban vs. rural). The goal of this section is to identify large and potentially vulnerable subgroups of adolescents and young people requiring special attention. Poverty Reduction Strategies and youth policies alike are meant to provide social safety nets and second chances to those who are disadvantaged. Such disadvantages can be the result of social situations (for example, being married as a child or living apart from both parents), lack of skills (for example, having less schooling), or poor access to material resources.

Section IV-B highlights the 10-14 year old age range, mindful that many countries have given little attention to this age group apart from educational entitlements, in order to identify the periods of time when young adolescents start their transition into potentially vulnerable phases of life. Most countries have commitments to getting young people into and through primary school, with the expectation that adolescents aged 10-14 will actually be in school. Policymakers often assume young people aged 10-14 are reliably under the protection of some kind of adult, ideally their parents. Many policies assume that they are a relatively stable population with the support of parents, and therefore many programs seek to engage parents. However, parents may or may not be present in the lives of these young people. This section is meant to highlight excluded populations of young adolescents, those who do not necessarily have all of the assumed social assets or who are not making the healthiest transition to adulthood. This includes: 
- those who are married very young;

- those who are out of school; and, where data are available,

- those who are living apart from one or both parents.

Young people who are not living with one or both parents are often orphans and are at a higher risk of participating in illegal and unsafe work and early marriage. Some may already be married and are thus living with their spouse or their spouse's family.

The onset of puberty brings substantial physical changes, as well as vulnerabilities to boys and, especially, to girls. Puberty for girls begins on average two years earlier than for boys. This fact, combined with very restrictive gender norms and limited assets, often leaves many girls with only their physical bodies as a core reliable asset. This asset can be potentially exploited for unsafe work; nonconsensual, unprotected, and underage sexual relations; and subject to preemptive marriage against their rights and will with the expectation that they will bear children as soon as possible.

Section IV-C highlights the context of sexual relations, whether inside or outside marriage, reports on marriage and pregnancy rates, and provides data related to the gender norms that often frame the onset and terms of sexual and marital relationships. In addition, data on HIV knowledge and testing, contraceptive use, antenatal care, and delivery assistance are included wherever possible.

In no case are there ideal data. However, the information presented is of very high quality and broadly representative (see Section II for a description of the representativeness of the data). These tables, graphs, and maps are meant to inform, but also to provoke questions and foster local engagement and action. They provide a foundation for a second generation of adolescent and youth programs more clearly targeted to large, neglected subgroups at critical moments. Because current youth policies have often failed to direct their resources to more vulnerable and harder-to-reach subgroups of adolescents, the benefits of these policies have been delivered to the better-off subgroups (typically urban, older, male, unmarried, and school-going populations). In most settings, adolescents who are rural, girls, younger, out-of-school, and married are neglected.

These materials are meant to inform local stakeholders' discussions, advocacy campaigns, and capacity building. The text that precedes each section and sub-section frames the data in a way that is appropriate for advocacy groups seeking to raise awareness about the needs of the young and vulnerable people in their countries of interest. The narrative and data are intended to be used by policy analysts and advocates alike to:

- come to conclusions;

- make decisions; and, where the data are unclear or lacking,

- motivate the seeking of clarification through targeted policy and program-oriented research. 
This project will be ongoing. As data for additional countries and more recent data from DHS or other national surveys such as the MICS, PAPFAM, and LSMS become available, new data guides will be produced. Additionally, as other tables or indicators of potential interest are identified they will be included in the future products. Your feedback is welcome at all times.

Finally, the Population Council and UNFPA would like to acknowledge the significant creative and analytic efforts and intellectual contributions of a number of colleagues in producing the narrative and tables, graphs, and maps as well as in the selection of the data presented. They are: Wendy Baldwin, John Bongaarts, Judith Bruce, Satvika Chalasani, Judy Diers, Gina Duclayan, Sarah Engebretsen, Rachel Goldberg, Nicole Haberland, Kelly Hallman, Robert Heidel, Paul Hewett, Laura Laski, Cynthia Lloyd, Ziad Mikati, Mark Montgomery, Jim Rosen, Christina Tse, Adam Weiner, and Sylvia Wong. A special thank you to Diana Graizbord and Marisela Morales is in order for their exceptional dedication and hard work in this undertaking.

Comments will be gratefully received; please contact: aweiner@popcouncil.org 


\section{II - Technical Notes}

1. All tables in this report are calculated from data collected for the 2005 Guinea Demographic and Health Survey, conducted by the Direction Nationale de la Statistique (DNS) Guinée. The Guinea DHS surveyed a nationally representative sample of 6,282 households. The information presented in Tables 1-8 and the corresponding figures and maps is based on all usual residents within the age group(s) of the selected households. Tables 9-26 and the corresponding figures and maps are based on 7,954 women ages 15-49 who responded to a more detailed individual questionnaire. The data are considered to be representative at the national, urban/rural, and regional levels for all age groups.

More information on the design of and results from the 2005 Guinea DHS is provided in the final report (Direction Nationale de la Statistique (DNS) (Guinée) et ORC Macro. 2006. Enquête Démographique et de Santé, Guinée 2005. Calverton, Maryland, U.S.A. : DNS et ORC Macro.) Information on the Demographic and Health Surveys, including reports, other publications, and original data, is available on the DHS website at http://www.measuredhs.com/.

2. The tables report values for which data are available for the 2005 Guinea DHS. Data are disaggregated into various groups to the extent that the data represented continue to be accurate. Parentheses around a number indicate that the statistic is based on 25-50 unweighted cases and data should be considered with caution. An asterisk indicates that the statistic is based on fewer than 25 individuals and the data, therefore, have been suppressed.

3. Maps are used selectively to depict sub-national or regional variation. These maps repeat information presented in chart or graphic form because maps are often easier to read and are of special interest to policymakers representing sub-national constituencies. 


\section{III - Investments in Adolescents as a Strategy for Achieving the Millennium Development Goals}

Investments in adolescents, a vital economic and social building block in most societies, are crucial in the developing world, where a rising proportion of the population is under the age of 24 . At the same time, as fertility declines, many countries have the possibility of a "demographic dividend," an increase in economic growth that comes about when a rising proportion of the population is of working age. When a country can productively employ these workers, they can provide resources to support the needs of those under 15 and over 60 .

The recently articulated and widely confirmed Millennium Development Goals - along with the broadly adopted Convention on the Elimination of All Forms of Discrimination Against Women and the Convention on the Rights of the Child - provide a framework of values and desirable actions with respect to children and adolescents. None of the goals of these compacts can be reached without substantial and prioritized investment in adolescent girls and other vulnerable adolescents:

- A strong economic base cannot be built without strengthening girls' and vulnerable youth's social and economic assets and thereby breaking the chain of intergenerational poverty. Women who have control of their assets are more likely than men to invest their assets to improve the health and education of their children and other family members. Investing in girls when it counts most is not simply a question of economic justice, but economic effectiveness.

- Universal primary school education is the minimum goal of most countries. The most deprived sector, in almost all countries, is rural girls. Though the female/male gap is narrowing, twothirds of those who have never been to school or are currently out of school are female. Girls' education, particularly participation and schooling during adolescence, is the best "development" investment in terms of: a) gaining the skills and knowledge necessary for working productively, b) economic returns, and c) social justice. Educated girls are more likely to avoid child marriage and have better maternal and child health outcomes. They are also more able and inclined to invest in the health and education of their sons and daughters particularly increasing the chances that their daughters will be educated.

- Dedicated efforts to reach girls before puberty are crucial steps on the road to gender equality. They help to prevent the worst human rights abuses (trafficking, female genital mutilation, exploitative domestic work, child marriage, forced sexual relations), conditions that are often closely related to high and unintended fertility, maternal mortality, and HIV infection.

- Investments in the poorest girls in the poorest countries are likely to reduce maternal illness and death. The same girls who are marginalized by their exclusion from school and residence in poor, rural, and ethnic minority communities are subject to child marriage and harmful traditional practices. They have limited access to health services and social support, and, as firsttime mothers, they bear the highest risks of maternal morbidity and mortality.

- The face of the HIV epidemic is increasingly young and female. Typical new incidence ratios for those aged 15-24 across sub-Saharan Africa are 3-to-1 female to male, and some countries are reporting ratios as high as 8-to-1. Without dedicated efforts, marginalized, disadvantaged girls are likely to bear a rising and disproportionate share of HIV infections. 
- In poor countries with high fertility rates, age at marriage and childbearing is a significant determinant of future population growth. Investments made in girls, to promote schooling, protect bodily integrity, and encourage legal and chosen marriage, could significantly improve their lives. Further, it may reduce burdens in their families and communities and foster reductions in the rate of population growth. 


\section{IV - Summary of DHS Data on Adolescents}

\section{A - Mapping the Vast Diversity among Adolescents}

Adolescents' capacities and opportunities vary, often dramatically, by age, gender, schooling, marital status, region and area (urban vs. rural) of residence and birth, and cultural affiliation. Understanding these diversities is critical to the development of relevant, targeted adolescent programs and policies. Much is at stake if programs are not properly targeted. The goals of these programs will not be met if they do not reach those with the greatest need. In fact, programs may inadvertently increase disadvantage by delivering services to those who need them least, while excluding those who need them most. The following tables highlight the basic differentials among adolescents' experiences and opportunities.

\section{Urban, Rural, and Peri-urban Youth}

Youth policies, both those aimed at building capacity and those meant to mitigate the effects of poverty, must address the distinctive environments in which young people live. Close attention needs to be given to the differences between the social and economic circumstances of urban and rural areas. In cities and towns, key educational and health resources are more readily available than in rural villages. Cities also present a more diverse set of income-earning opportunities. But it is far from obvious that young people - especially those who are poor - are in a position to take advantage of these urban resources and opportunities. For the urban poor, school enrollment rates fall well below the rates of wealthier urban residents. In multiple dimensions of health, the urban poor hardly fare better than rural villagers. To some, the diversity of urban living standards may be seen in a positive light, suggesting possibilities for upward mobility. But to many poor girls and boys, this same diversity may be interpreted quite differently, as evidence of an unbridgeable gulf between their circumstances and those of the urban elites. The social risks of city life may jeopardize both poor young people and those who are better off, as is clear from higher urban rates of HIV and AIDS.

Recent estimates by UN-Habitat ${ }^{1}$ put the number of slum-dwellers in developing countries at nearly 1 billion. Yet the urban poor, especially poor adolescents, have rarely been the focus of poverty alleviation policies. Particular attention needs to be given to the young people who live in peri-urban areas, those areas surrounding urban areas. These peri-urban zones often lie outside the geographic scope of local and municipal governments, and therefore may be neglected in terms of service delivery. It is believed that peri-urban areas are among the fastest-growing locations in the developing world.

In about half of recent DHS surveys, it is possible to pinpoint the locations of the neighborhoods where interviewing takes place and, in principle, this information could be used to identify peri-urban and slum communities. In most cases, however, there are too few observations to allow researchers to reliably characterize the young people of these communities. Nevertheless, urban youth as a whole can be distinguished from rural youth, and those living in poor households can be singled out for special

\footnotetext{
${ }^{1}$ United Nations Human Settlements Programme (UN-Habitat). 2003. The challenge of slums: global report on human settlements. UN-Habitat: Nairobi.
} 
attention. Recent migrants, especially among the young, may well live in unsettled circumstances lacking adequate youth-friendly services. To understand the opportunities and risks, it is recommended that rural and urban youth be distinguished. Further distinctions on the basis of living standards are also in order. Where sample sizes permit, the DHS surveys that provide the locations of sampling clusters can be analyzed to characterize the environments faced by slum-dwelling adolescents and those who live in peri-urban areas. This is an area in need of further exploration and is beyond the scope of this publication.

Table 1: Population Distribution

\begin{tabular}{|c|c|c|}
\hline \multicolumn{3}{|c|}{$\begin{array}{l}\text { Urban-rural residence and population } \\
\text { distribution (percent) }\end{array}$} \\
\hline & Urban & Rural \\
\hline \multicolumn{3}{|l|}{ Girls } \\
\hline $10-14$ & 33.0 & 67.0 \\
\hline $15-19$ & 38.9 & 61.1 \\
\hline $20-24$ & 39.0 & 61.0 \\
\hline \multicolumn{3}{|l|}{ Boys } \\
\hline $10-14$ & 29.2 & 70.8 \\
\hline $15-19$ & 42.6 & 57.4 \\
\hline $20-24$ & 54.5 & 45.5 \\
\hline
\end{tabular}


Figure 1: Urban-Rural Residence

\begin{tabular}{|c|c|c|c|}
\hline \multicolumn{2}{|c|}{ Girls 10-14 } & Girls 15-19 & Girls 20-24 \\
\hline & $\begin{array}{l}\text { - Urban } \\
\text { - Rural }\end{array}$ & $\begin{array}{l}\text { - Urbar } \\
\text { - Rural }\end{array}$ & $\begin{array}{l}\text { - Urban } \\
\text { - Rural }\end{array}$ \\
\hline Bo & -14 & Boys 15-19 & Boys 20-24 \\
\hline $51 \%$ & $\begin{array}{l}\text { Urban } \\
\text { Rural }\end{array}$ & $\begin{array}{l}\text { - Urbar } \\
\text { - Rural }\end{array}$ & $\begin{array}{l}\text { - Urban } \\
\text { - Rural }\end{array}$ \\
\hline
\end{tabular}

\section{Parental presence in the household: Living with both, one, or no parents}

Many social policies, including health policies, assume that young adolescents are living with at least one or, ideally, both parents. It is presumed that parents (or even grandparents) may be relied upon to provide income, moral or logistical support, housing, and protection. Many programs directed at this age group assume some level of engagement by parents and therefore may seek to have parental input on important policies.

Though the presence of both parents does not ensure that a young person will have all of the presumed benefits, the absence of one or both parents may be cause for concern. Adolescents living apart from one or both parents may be socially isolated, may not have the economic resources needed to go to school, and may have to carry some income-generating burden both for themselves and for family members. Partial or total parental absence may reduce adolescents' access to health care and even the assurance of their safety; studies have recently confirmed that adolescents who are single or double orphans have higher HIV rates. In light of these disadvantages, some countries have begun to target entitlements and policies to disadvantaged subpopulations. These include cash transfer programs to disadvantaged children, prioritizing those in the lower-income quintiles living with one (or no) parent, and Individual Development Accounts (i.e., savings accounts) for orphaned children. Thus, information about parental presence in households is an important factor in thinking about the targeting of 
resources. It is also valuable to note substantial variation by sub-national region and between boys and girls. When young adolescents aged 10-14 are living with only one parent, they nearly always live with their mother and not their father. Thus the disadvantages of the mother (in income earning, protection, and social power, among others) may translate into special burdens and risks for the children, especially girls.

Table 2: Parental Residence in Household

\begin{tabular}{|c|c|c|c|c|c|c|c|c|}
\hline \multicolumn{9}{|c|}{ Parental residence in household $(\mathrm{HH})$ among $10-14$ year old youth (percent) } \\
\hline \multirow[t]{2}{*}{ Region } & \multicolumn{2}{|c|}{$\begin{array}{c}\text { Both parents in } \\
\mathrm{HH}\end{array}$} & \multicolumn{2}{|c|}{$\begin{array}{c}\text { Mother only in } \\
\mathrm{HH} \\
\end{array}$} & \multicolumn{2}{|c|}{$\begin{array}{c}\text { Father only in } \\
\mathrm{HH}\end{array}$} & \multicolumn{2}{|c|}{$\begin{array}{c}\text { Neither parent in } \\
\mathrm{HH}\end{array}$} \\
\hline & Girls & Boys & Girls & Boys & Girls & Boys & Girls & Boys \\
\hline Boké & 68.2 & 68.5 & 6.9 & 6.7 & 4.6 & 7.1 & 20.4 & 17.4 \\
\hline Conakry & 42.2 & 53.3 & 14.7 & 11.4 & 6.2 & 11.0 & 35.9 & 23.9 \\
\hline Faranah & 63.9 & 63.4 & 11.1 & 10.7 & 9.2 & 10.3 & 15.9 & 15.6 \\
\hline Kankan & 72.6 & 68.6 & 7.1 & 6.6 & 7.6 & 10.3 & 12.8 & 14.5 \\
\hline Kindia & 66.2 & 68.7 & 6.3 & 6.0 & 6.0 & 9.5 & 21.5 & 15.8 \\
\hline Labé & 49.6 & 43.4 & 19.9 & 20.9 & 6.0 & 9.1 & 23.6 & 26.5 \\
\hline Mamou & 57.1 & 63.1 & 12.5 & 11.8 & 4.8 & 5.6 & 25.1 & 19.6 \\
\hline N'Zérékoré & 62.1 & 56.7 & 12.4 & 15.5 & 8.5 & 9.0 & 17.1 & 18.8 \\
\hline Urban & 48.0 & 54.4 & 14.2 & 13.4 & 6.2 & 8.8 & 31.2 & 23.2 \\
\hline Rural & 65.7 & 62.9 & 10.1 & 10.6 & 7.0 & 9.4 & 17.0 & 17.2 \\
\hline National & 59.8 & 60.4 & 11.5 & 11.4 & 6.7 & 9.2 & 21.6 & 18.9 \\
\hline
\end{tabular}

Read the first column of data as "Percent of 10-14 year old girls who live with both parents." 
Figure 2: Parental Residence in Household among 10-14 Year Olds (percent)

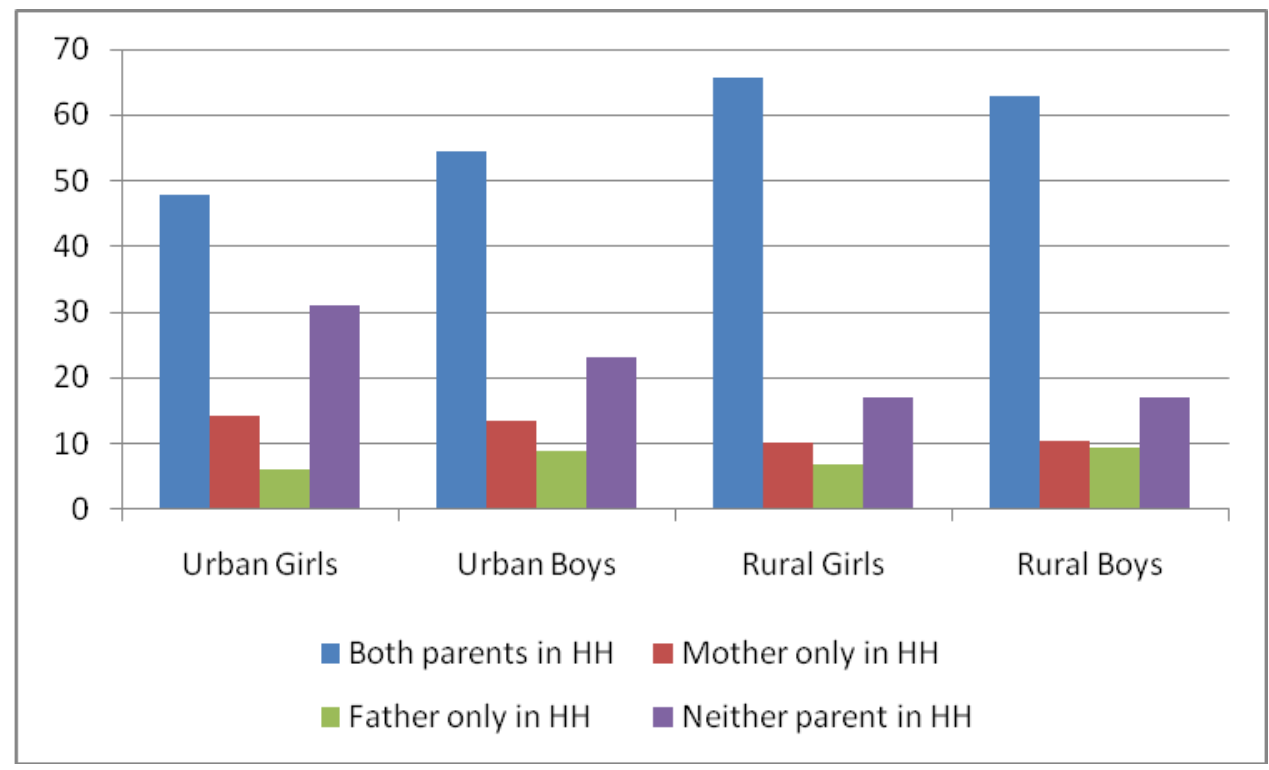


Table 3: Parental Survival

\begin{tabular}{|c|c|c|c|c|c|c|c|c|}
\hline \multirow{3}{*}{ Region } & \multicolumn{8}{|c|}{ Parental survival among $10-14$ year olds (percent) } \\
\hline & \multicolumn{2}{|c|}{$\begin{array}{c}\text { Both parents } \\
\text { alive }\end{array}$} & \multicolumn{2}{|c|}{$\begin{array}{l}\text { Only mother } \\
\text { alive }\end{array}$} & \multicolumn{2}{|c|}{$\begin{array}{l}\text { Only father } \\
\text { alive }\end{array}$} & \multicolumn{2}{|c|}{$\begin{array}{c}\text { Neither parent } \\
\text { alive }\end{array}$} \\
\hline & Girls & Boys & Girls & Boys & Girls & Boys & Girls & Boys \\
\hline Boké & 89.7 & 90.9 & 5.7 & 6.1 & 2.4 & 2.2 & 2.3 & 0.8 \\
\hline Conakry & 81.0 & 82.4 & 9.7 & 7.7 & 2.8 & 4.9 & 6.5 & 5.0 \\
\hline Faranah & 89.2 & 87.9 & 5.3 & 9.3 & 3.7 & 2.2 & 1.8 & 0.7 \\
\hline Kankan & 91.7 & 89.1 & 4.8 & 7.9 & 2.3 & 2.4 & 1.2 & 0.6 \\
\hline Kindia & 90.7 & 92.1 & 4.1 & 4.5 & 3.3 & 2.8 & 1.9 & 0.7 \\
\hline Labé & 85.4 & 77.7 & 7.1 & 12.7 & 5.7 & 5.2 & 1.8 & 4.4 \\
\hline Mamou & 92.5 & 91.3 & 5.8 & 5.4 & 1.0 & 2.2 & 0.7 & 1.1 \\
\hline N'Zérékoré & 89.3 & 83.4 & 5.8 & 12.0 & 3.9 & 2.8 & 1.1 & 1.8 \\
\hline Urban & 86.1 & 83.7 & 7.6 & 10.1 & 2.7 & 2.9 & 3.7 & 3.3 \\
\hline Rural & 89.4 & 87.6 & 5.4 & 7.9 & 3.6 & 3.2 & 1.6 & 1.3 \\
\hline National & 88.4 & 86.5 & 6.1 & 8.6 & 3.3 & 3.1 & 2.3 & 1.9 \\
\hline
\end{tabular}

Read the first column of data as "Percent of 10-14 year old girls with both parents alive."

Figure 3: Parental Survival among 10-14 Year Olds (percent)

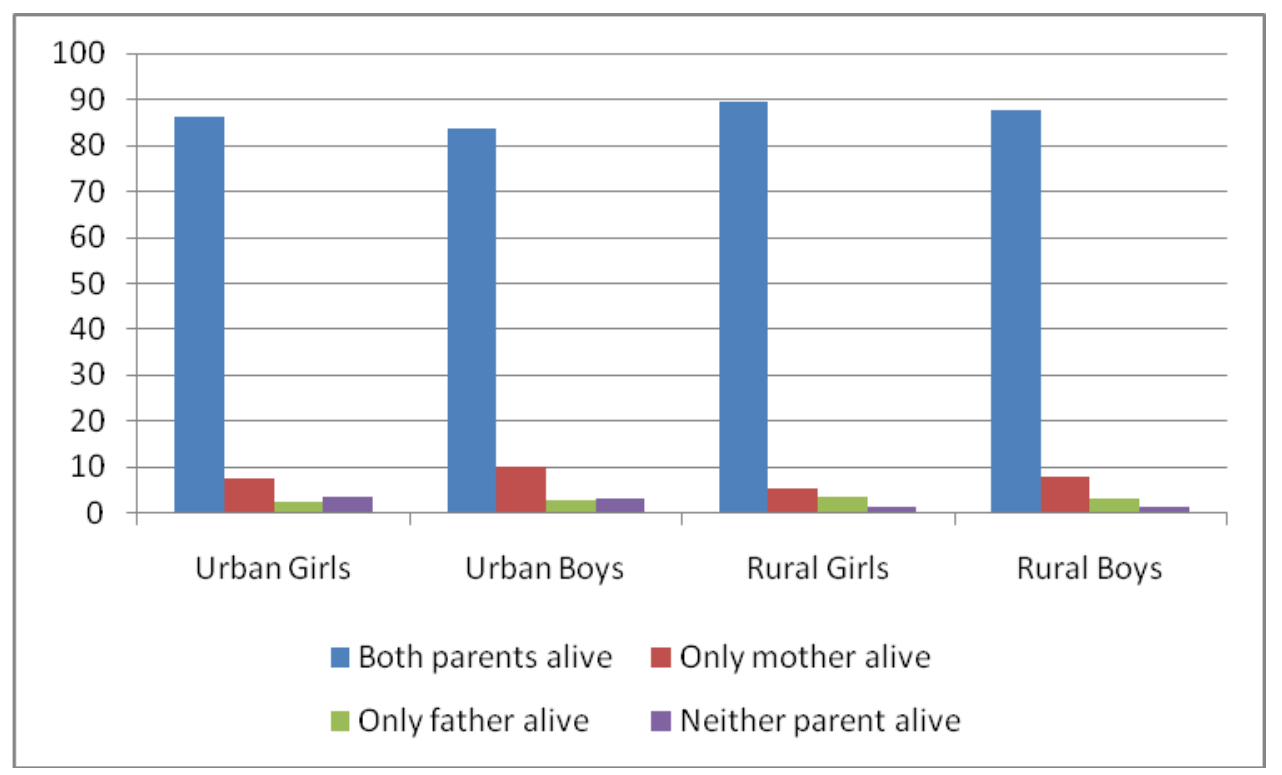




\section{School enrollment during adolescence: $A$ key health and development strategy}

Education is a critical component of a healthy transition to adulthood. During childhood and adolescence, learning occurs more intensely than during other phases of life. During adolescence, young people develop physical and cognitive skills and acquire the knowledge and information necessary to becoming healthy, productive adults. Providing quality education in a safe environment and keeping children in school is a cross-cutting strategy that links different development priorities. For example, being in school has been associated with delays in the age at first sex, marriage, and childbearing. Appropriate, targeted policies and programs that help to keep young people enrolled throughout adolescence and connected to the social network that schools provide can have important impacts on their personal development and can minimize their vulnerabilities to the challenges that exist outside of the school environment.

Schooling is the most widely recognized and articulated right of adolescents, and this is reflected in government policymaking directed at adolescents. Understandably, policymakers concerned with reproductive health and HIV prevention and management have directed much attention toward schoolbased HIV prevention programs. However, while it is obviously important to reach those in school, there has been insufficient attention to the (often starkly elevated) reproductive health risks of those adolescents who are out of school, especially girls. This has resulted in a shortage of effective programs to reach them.

Analyses of schooling and its relationship to reproductive health behavior have often focused on correlations among the numbers of years in schooling and delays in the time of marriage and first birth, lower lifetime fertility, and higher earnings in the labor market. ${ }^{2}$ A recent analysis of 48 countries - the majority of which are low-income developing countries - conducted by Cynthia Lloyd focused on the reproductive health benefits for girls and boys of being in school during adolescence, regardless of educational attainment, school quality (as measured in students' competence), or grade-for-age status. ${ }^{3}$ Lloyd's cross-country analysis, using the recently available Demographic and Health Surveys, centered on the reproductive behavior of adolescents between the ages of 15 and 17 who are enrolled in school. Perhaps her most important finding had to do with the proportion of girls in this age group who report having ever had sex. School-going girls (almost exclusively unmarried) are substantially less likely than out-of-school girls (both married and unmarried) to report having sexual relations. This holds even in sub-Saharan Africa, where a large proportion of 15-17 year olds who are in school are studying at primary level. The rising percentage of adolescents attending school does not appear to reduce the strength of the positive association between going to school and favorable reproductive health outcomes. It appears that adolescents who are enrolled in school, especially girls, are better informed

\footnotetext{
${ }^{2}$ Summers, Lawrence. (1994) Investing in All the People, EDI Seminar Paper No. 45, Economic Development Institute of The World Bank; Odaga, Adhiambo and Ward Heneveld (1995). "Girls and Schools in Sub-Saharan Africa," World Bank Technical paper 298.

3 Lloyd, Cynthia B. 2006. "Schooling and adolescent reproductive behavior in developing countries." Paper commissioned by the United Nations Millennium Project for the report Public Choices, Private Decisions: Sexual and Reproductive Health and the Millennium Development Goals. New York: UN Millennium Project.
} 
and motivated to avoid sexually transmitted infections and pregnancy. ${ }^{4}$ Enrolled girls are less likely than non-students of the same age to have had sex, and, if they are sexually active, they are more likely to use contraception. The risk of dropping out of school increases significantly for girls who have had premarital sex. ${ }^{5}$ In addition, girls who are now at school, and who have had few or no interruptions to their past schooling, are less likely than girls with a history of schooling interruptions to become pregnant. They are also less likely to drop out if they do become pregnant. ${ }^{6}$

Table 4A: School Enrollment among 10-14 Year Olds

\begin{tabular}{|c|c|c|c|c|c|c|}
\hline \multicolumn{7}{|c|}{ School enrollment among $10-14$ year olds ${ }^{a}$ (percent) } \\
\hline \multirow[b]{2}{*}{ Region } & \multicolumn{3}{|c|}{ Females } & \multicolumn{3}{|c|}{ Males } \\
\hline & $\begin{array}{l}\text { Not in } \\
\text { school }\end{array}$ & $\begin{array}{l}\text { Attending } \\
\text { primary }\end{array}$ & $\begin{array}{l}\text { Attending } \\
\text { secondary }\end{array}$ & $\begin{array}{l}\text { Not in } \\
\text { school }\end{array}$ & $\begin{array}{l}\text { Attending } \\
\text { primary }\end{array}$ & $\begin{array}{l}\text { Attending } \\
\text { secondary }\end{array}$ \\
\hline Boké & 47.1 & 49.6 & 3.4 & 43.0 & 50.9 & 6.1 \\
\hline Conakry & 23.9 & 60.4 & 15.7 & 9.3 & 79.5 & 10.9 \\
\hline Faranah & 52.8 & 44.8 & 2.5 & 34.3 & 62.3 & 3.4 \\
\hline Kankan & 64.1 & 33.4 & 2.5 & 61.5 & 36.2 & 2.3 \\
\hline Kindia & 51.7 & 46.7 & 1.6 & 35.4 & 62.0 & 2.7 \\
\hline Labé & 59.8 & 37.8 & 2.4 & 44.4 & 51.7 & 3.9 \\
\hline Mamou & 58.0 & 39.1 & 2.8 & 45.0 & 54.2 & 0.8 \\
\hline N'Zérékoré & 44.3 & 55.0 & 0.8 & 38.9 & 59.0 & 2.1 \\
\hline Urban & 26.4 & 63.4 & 10.2 & 15.4 & 75.4 & 9.0 \\
\hline Rural & 59.4 & 39.3 & 1.2 & 48.8 & 49.4 & 1.8 \\
\hline National & 48.6 & 47.3 & 4.2 & 39.0 & 57.0 & 3.9 \\
\hline
\end{tabular}

Read the first column of data as "Percent of 10-14 year old females not in school."

${ }^{a}$ Enrollment at any time during current school year.

\footnotetext{
${ }^{4}$ Lloyd, Cynthia B. 2008. "The role of schools in promoting sexual and reproductive health among adolescents in developing countries," in S. Malarcher (ed.), Social Determinants of Sexual and Reproductive Health: Informing Future Research and Programme Needs. Geneva: World Health Organization.

${ }^{5}$ Ibid.

${ }^{6}$ Grant, Monica and Kelly Hallman. 2006. "Pregnancy-related school dropout and prior school performance in South Africa," Policy Research Division Working Paper no. 212. New York: Population Council.
} 
Table 4B: School Enrollment among 15-19 Year Olds

\begin{tabular}{|c|c|c|c|c|c|c|}
\hline \multicolumn{7}{|c|}{ School enrollment among 15-19 year olds ${ }^{\mathrm{a}}$ (percent) } \\
\hline \multirow[b]{2}{*}{ Region } & \multicolumn{3}{|c|}{ Females } & \multicolumn{3}{|c|}{ Males } \\
\hline & $\begin{array}{l}\text { Not in } \\
\text { school }\end{array}$ & $\begin{array}{l}\text { Attending } \\
\text { primary }\end{array}$ & $\begin{array}{l}\text { Attending } \\
\text { secondary }\end{array}$ & $\begin{array}{l}\text { Not in } \\
\text { school }\end{array}$ & $\begin{array}{l}\text { Attending } \\
\text { primary }\end{array}$ & $\begin{array}{l}\text { Attending } \\
\text { secondary }\end{array}$ \\
\hline Boké & 71.9 & 14.1 & 14.0 & 48.2 & 15.2 & 36.6 \\
\hline Conakry & 43.0 & 10.9 & 45.8 & 23.8 & 17.4 & 58.8 \\
\hline Faranah & 66.4 & 14.4 & 19.2 & 33.7 & 24.0 & 42.2 \\
\hline Kankan & 79.7 & 9.5 & 10.8 & 54.7 & 16.5 & 28.8 \\
\hline Kindia & 70.8 & 14.3 & 15.0 & 48.5 & 28.0 & 23.5 \\
\hline Labé & 68.5 & 9.6 & 21.9 & 58.1 & 9.2 & 32.7 \\
\hline Mamou & 76.9 & 13.1 & 10.0 & 40.4 & 27.1 & 32.5 \\
\hline N'Zérékoré & 63.5 & 17.1 & 19.5 & 35.6 & 28.8 & 35.6 \\
\hline Urban & 42.9 & 15.2 & 41.8 & 20.5 & 19.2 & 60.3 \\
\hline Rural & 79.3 & 12.2 & 8.5 & 55.1 & 23.3 & 21.7 \\
\hline National & 65.1 & 13.3 & 21.5 & 40.3 & 21.5 & 38.1 \\
\hline
\end{tabular}

Read the first column of data as "Percent of 15-19 year old females not in school."

${ }^{a}$ Enrollment at any time during current school year.

Figure 4: School Enrollment among 15-19 Year Olds

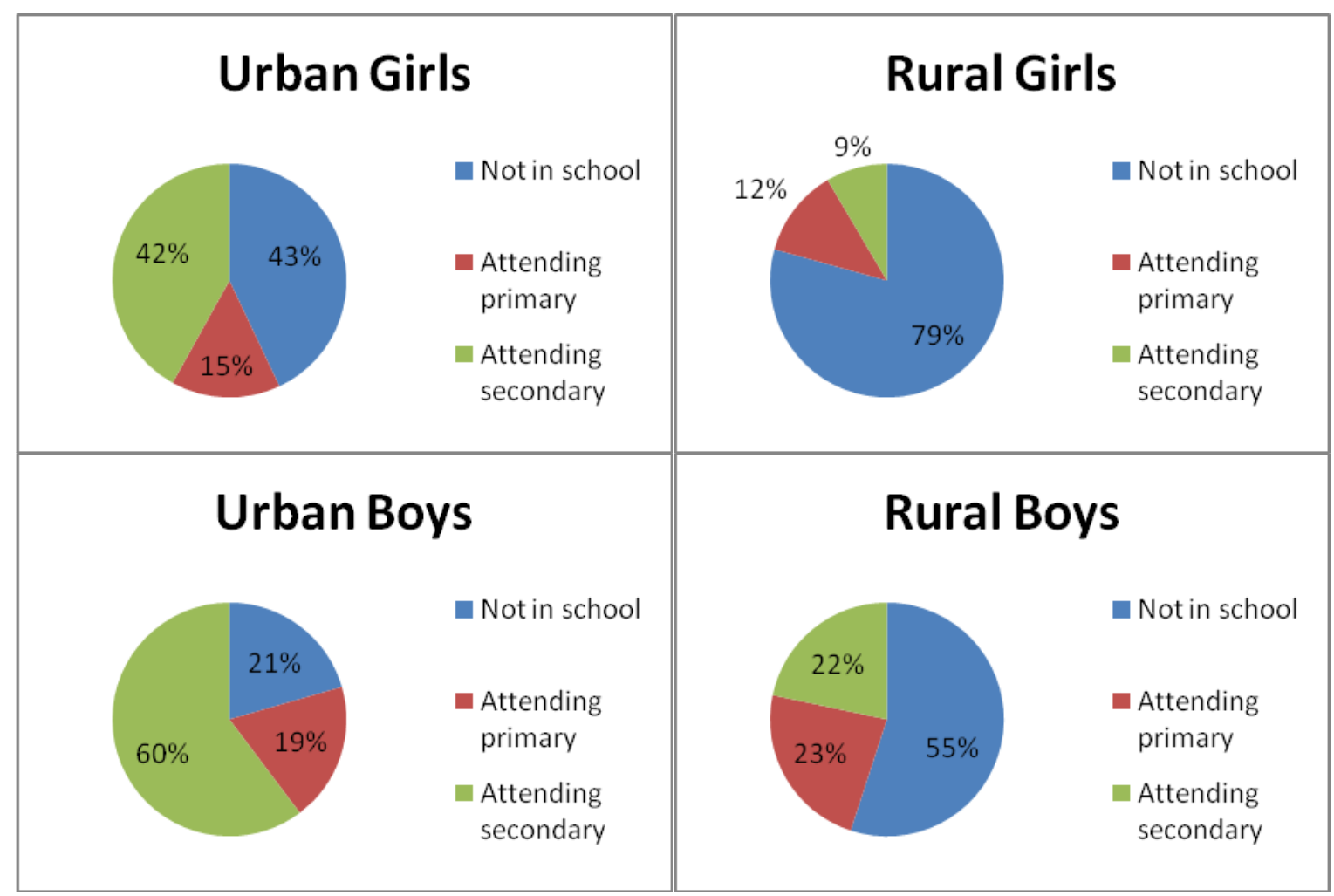




\section{Married girls: A neglected category}

The majority of sexually active girls aged 15-19 in developing countries are married. Child marriage remains a fact of life in largely rural regions in South Asia and Latin America and, crucially, in many subSaharan African countries that have HIV prevalence above 5 percent in populations of women attending antenatal clinics (defined as a mature and generalized epidemic). If present patterns continue, in the next decade over 100 million girls will be married before age 18; approximately one in seven of these girls will be under age 15 (2006 Population Council analysis of DHS and UN country data).

Social and health policies have paid minimal attention to child brides as a separate category, typically grouping all married women together regardless of current age, age at marriage, or characteristics of the marital partnership. Initiatives meant to serve young people have similarly overlooked both girls at risk of child marriage and married girls, directing their attention mainly to unmarried, often schoolgoing, populations.

Of particular concern may be the exceptional risks run by girls who have become widowed, divorced, or abandoned because of the nature of their marriage (its inequality, the death of a husband from HIV) and the substantial social exclusion and economic risk they face post-marriage.

Married girls face a host of other challenges that limit their ability to protect their health and well-being. Child brides often experience a sudden shrinking of their social networks, leaving them with few, if any, friends and peers. This social isolation can close them off from essential (and in many settings constitutionally guaranteed) rights. Married girls also typically have low educational attainment and no schooling options, limited control over resources, highly restricted mobility, and little or no power in their new households. ${ }^{7}$ Thus, married girls may face significant challenges in negotiating safe sexual relations. A key building block of effective policy is to address child marriage where it exists, create programs that increase the safety of marriage in any case, and provide appropriate supports for the young married and the youngest first-time mothers. See Table 12 for data on child marriage.

\footnotetext{
${ }^{7}$ Haberland, Nicole, Erica Chong, and Hillary J. Bracken. 2003. "Married Adolescents: An Overview," paper prepared for the WHO/UNFPA/Population Council Technical Consultation on Married Adolescents. WHO: Geneva.
} 
Table 5: Marital Status among Females

\begin{tabular}{|c|c|c|c|c|c|c|}
\hline \multicolumn{7}{|c|}{ Marital status among females $15-24$ (percent) } \\
\hline \multirow{2}{*}{ Region } & \multicolumn{2}{|c|}{$\begin{array}{l}\text { Currently married or } \\
\text { in union }\end{array}$} & \multicolumn{2}{|c|}{$\begin{array}{l}\text { Separated, divorced } \\
\text { or widowed }\end{array}$} & \multicolumn{2}{|c|}{ Never-married } \\
\hline & $\begin{array}{c}15-19 \\
\text { year olds }\end{array}$ & $\begin{array}{c}20-24 \\
\text { year olds }\end{array}$ & $\begin{array}{c}15-19 \\
\text { year olds }\end{array}$ & $\begin{array}{c}20-24 \\
\text { year olds }\end{array}$ & $\begin{array}{c}15-19 \\
\text { year olds }\end{array}$ & $\begin{array}{c}20-24 \\
\text { year olds }\end{array}$ \\
\hline Boké & 37.0 & 80.7 & 3.1 & 4.4 & 59.9 & 14.9 \\
\hline Conakry & 27.0 & 62.9 & 3.2 & 7.0 & 69.8 & 30.1 \\
\hline Faranah & 44.2 & 83.0 & 1.0 & 1.5 & 54.9 & 15.5 \\
\hline Kankan & 57.2 & 90.0 & 1.3 & 0.0 & 41.6 & 10.0 \\
\hline Kindia & 30.5 & 80.6 & 0.9 & 0.0 & 68.6 & 19.4 \\
\hline Labé & 26.1 & 76.6 & 5.4 & 6.3 & 68.5 & 17.0 \\
\hline Mamou & 39.9 & 84.8 & 1.6 & 2.4 & 58.6 & 12.8 \\
\hline N'Zérékoré & 33.9 & 75.5 & 1.9 & 2.6 & 64.1 & 21.8 \\
\hline Urban & 22.0 & 59.7 & 2.5 & 5.4 & 75.5 & 34.9 \\
\hline Rural & 44.4 & 88.0 & 2.2 & 1.9 & 53.4 & 10.1 \\
\hline National & 35.6 & 77.1 & 2.3 & 3.3 & 62.1 & 19.7 \\
\hline
\end{tabular}

Read the first column of data as "Percent of 15-19 year old females who are currently married or in a union." 
Figure 5: Marital Status among Females (percent)

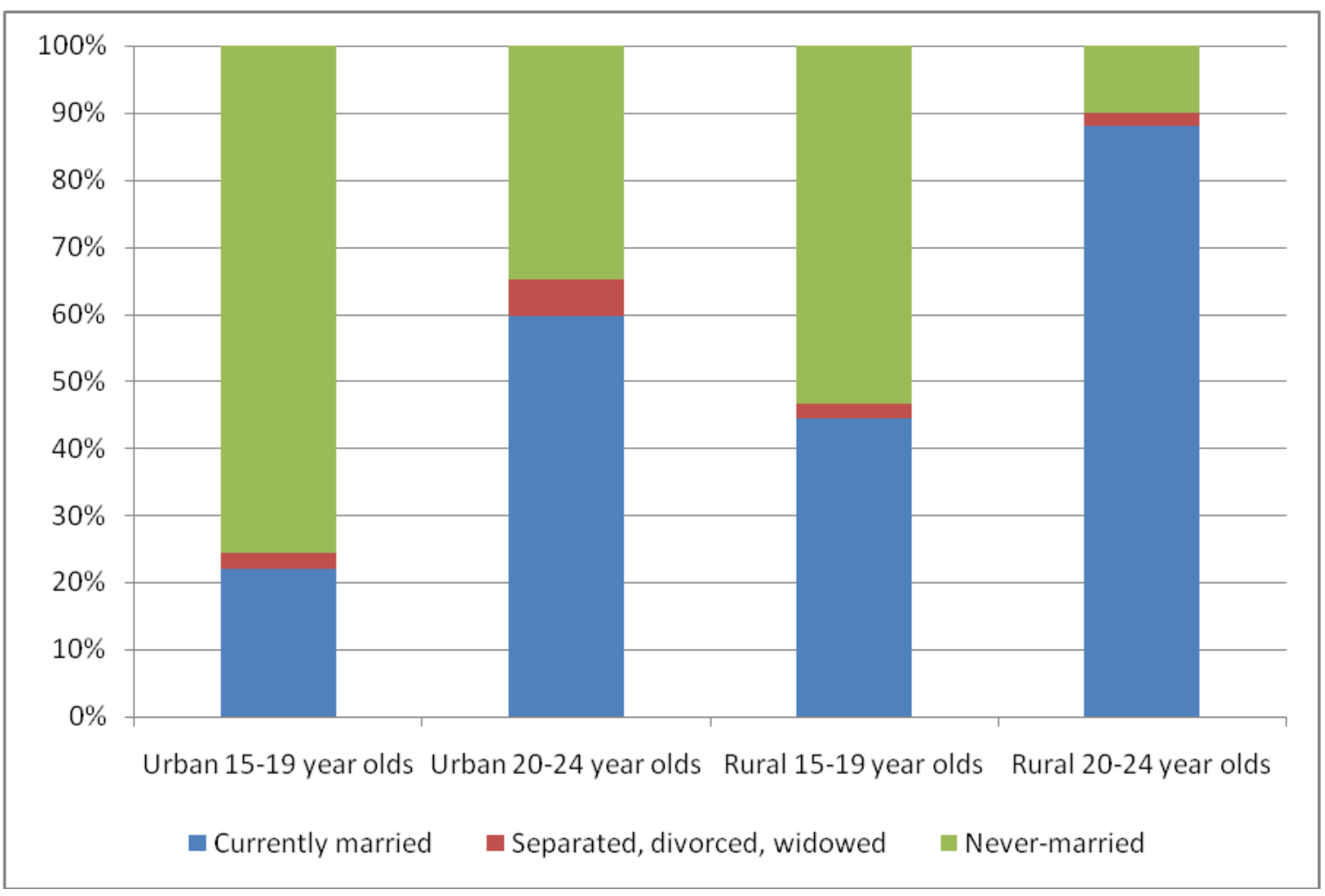




\section{B - Key Transitions among Very Young Adolescents that Lead to Disadvantage}

Very young adolescents (children aged 10-14) are undergoing tremendous physical, emotional, social, and intellectual changes. During this period, many very young adolescents go through puberty, have their first sexual experiences, and in the case of girls, may be married prematurely. For most children, early adolescence is marked by good health and stable family circumstances, but it can also be a period of vulnerability because of intense and rapid transitions to new roles and responsibilities as caretakers, workers, spouses, and parents. In many countries, the impact of HIV, poverty, and political and social conflict on families and communities has eroded traditional safety nets and increased the vulnerability of young adolescents.

It is therefore critical for policymakers and program managers to consider very young adolescents' special opportunities as well as their vulnerabilities. In most countries, there are policies for children to attend school at this age, and one finds a higher proportion of this age group in school compared to older adolescents. Capitalizing on this is critical. However, it is also important to note that many young adolescents are not in school and therefore may be at higher risk for many negative outcomes. Aside from neglect within the education sector, very young adolescents have been particularly neglected by policymakers and are not reached by most conventional child health, maternal health, and women's empowerment programs.

We must learn more about the timing, nature, and consequences of the key transitions young adolescents undergo, and in particular how these play out among the most vulnerable groups. Initiating programs at or around this age is an acknowledgment of young people's evolving capacity. Strategic timing of interventions allows for positive outcomes before the circumstances of young adolescents' lives are set.

\section{Support for the extremely vulnerable youth}

As previously mentioned, young people between the ages of 10 and 14 begin their transition out of childhood and enter puberty. This time often brings greater responsibility within the home and exposes girls, in particular, to societal pressures to enter marriage, sexual relations, and childbearing. When children of this age are neither living with their parents nor attending school, it is a great cause for concern. There is a good chance that they are not receiving the familial or peer support to properly deal with the challenges they face and are not being given adequate opportunity to develop into productive members of society. In some settings, young female adolescents are domestic workers, migrants from rural communities in search of work and an education, or are fleeing a forced marriage. Others may already be child brides and are now living with their spouse and, possibly, his family. These youth are among the least likely to seek out and receive social services and therefore require a proactive set of prescriptions to minimize their vulnerability to exploitation. 
Table 6: Adolescents Not in School and Not Living with Either Parent

\begin{tabular}{|c|c|c|}
\hline \multicolumn{3}{|c|}{$\begin{array}{c}\text { Percent of 10-14 year olds not in school and } \\
\text { not living with either parent }\end{array}$} \\
\hline Region & Girls & Boys \\
\hline Boké & 10.2 & 8.0 \\
\hline Conakry & 16.3 & 5.8 \\
\hline Faranah & 9.2 & 3.6 \\
\hline Kankan & 7.3 & 9.2 \\
\hline Kindia & 10.7 & 7.1 \\
\hline Labé & 14.7 & 14.8 \\
\hline Mamou & 12.7 & 9.5 \\
\hline N'Zérékoré & 9.6 & 8.7 \\
\hline Urban & 14.3 & 6.6 \\
\hline Rural & 9.9 & 9.2 \\
\hline National & $\mathbf{1 1 . 3}$ & $\mathbf{8 . 4}$ \\
\hline
\end{tabular}

Read the first column of data as "Percent of 10-14 year old girls not in school and not living with either parent." 
Figure 6: Percent of 10-14 Year Olds Not in School and Not Living with Either Parent

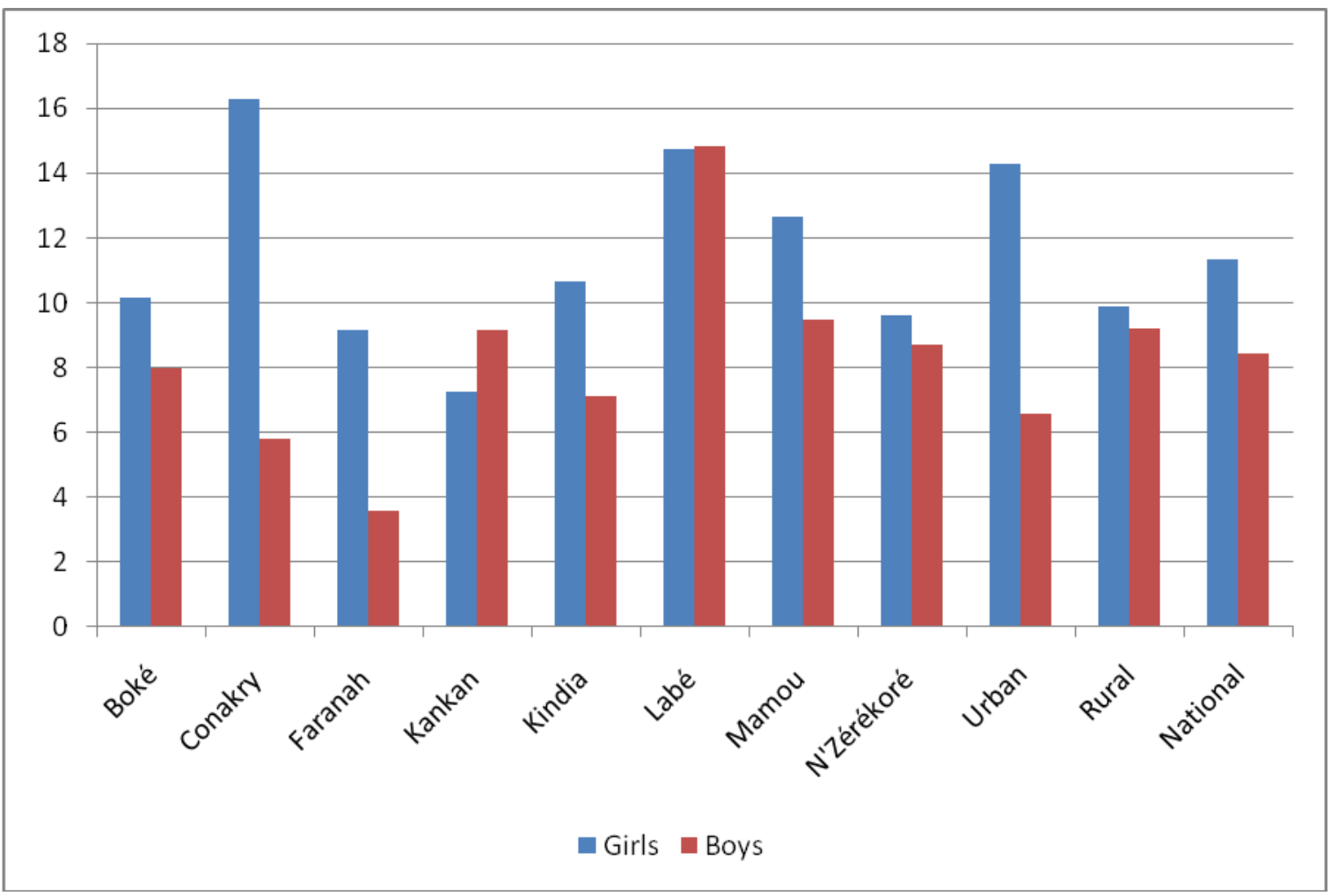


Map 1: Females (10-14) Not in School and Not Living with Either Parent

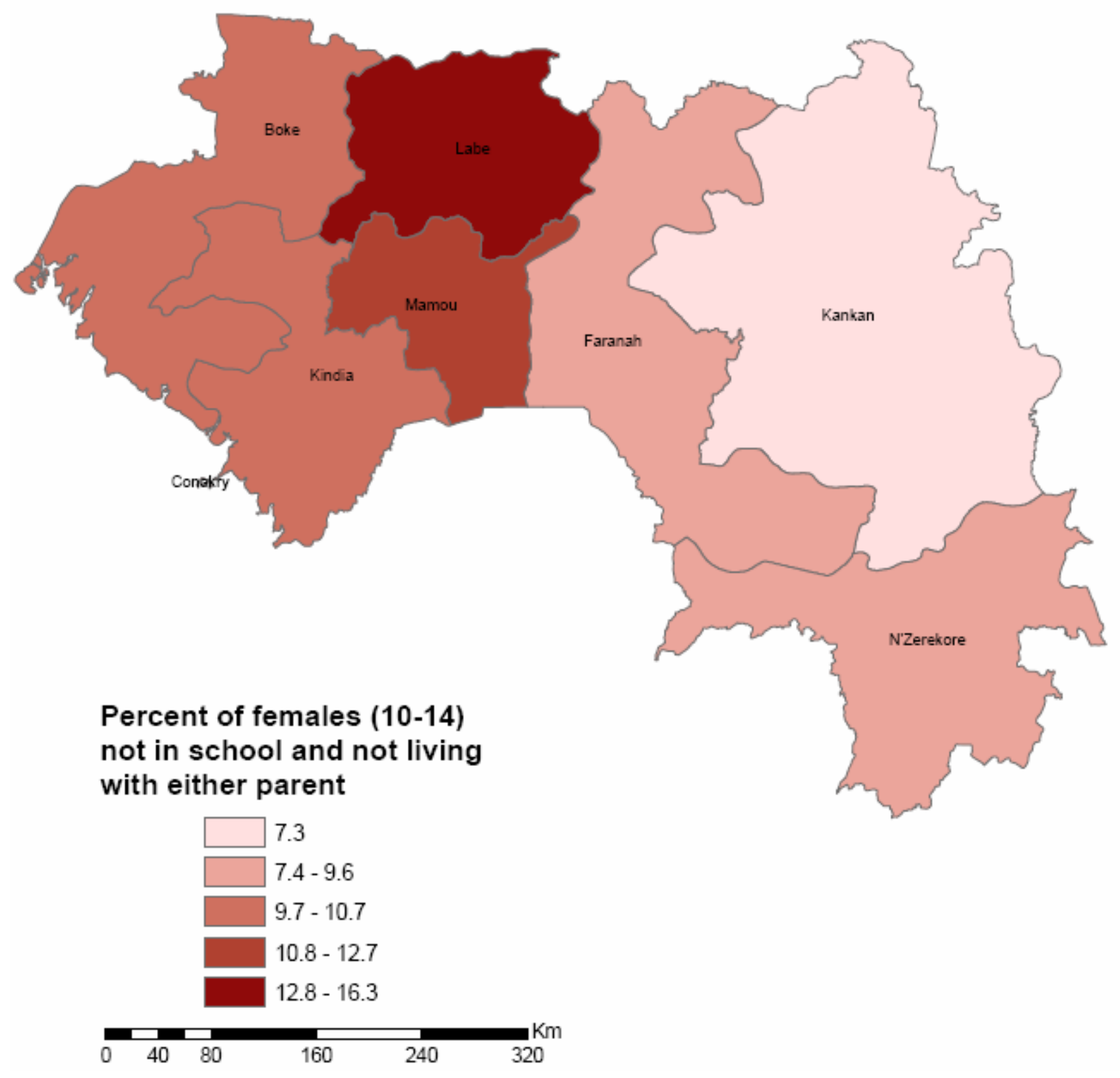




\section{Differentiation of services for out-of-school youth}

The increase in school participation rates over the last 20 to 30 years in the developing world means that greater numbers of young people are enrolled in school during adolescence, with many still in school beyond the age of 15 . Despite this trend, there are still major differences in school participation along the lines of gender, urban/rural residence, and marital status, among others. A young person who is out of school requires a very different set of interventions than those still in school, given that the former, especially females, are more likely to be married, have children, and be sexually active. These circumstances carry a host of reproductive health risks that will need to be addressed outside of the school environment and in a way that is accessible to these at-risk youth who may have limited mobility due to extremely high levels of responsibility within the household or security issues within their communities.

Table 7: School Enrollment among 10-17 Year Olds

\begin{tabular}{|c|c|c|c|c|}
\hline \multirow{2}{*}{ Percent of adolescents 10-17 currently in school } \\
\hline \multirow{2}{*}{ Age } & \multicolumn{2}{|c|}{ Urban } & \multicolumn{2}{c|}{ Rural } \\
\cline { 2 - 5 } & Girls & Boys & Girls & Boys \\
\hline 10 & 74.3 & 86.2 & 42.1 & 49.7 \\
\hline 11 & 79.7 & 89.0 & 42.7 & 51.4 \\
\hline 12 & 72.6 & 89.0 & 39.9 & 49.3 \\
\hline 13 & 68.5 & 81.8 & 36.8 & 55.8 \\
\hline 14 & 75.4 & 76.5 & 39.5 & 50.7 \\
\hline 15 & 76.0 & 80.0 & 25.7 & 46.6 \\
\hline 16 & 61.9 & 82.8 & 25.9 & 52.1 \\
\hline 17 & 52.4 & 83.3 & 19.1 & 44.3 \\
\hline
\end{tabular}
Read the first column of data as “Percent of 10-17 year old girls living in
urban areas who are currently in school."


Figure 7: School Enrollment among 10-17 Year Olds (percent)

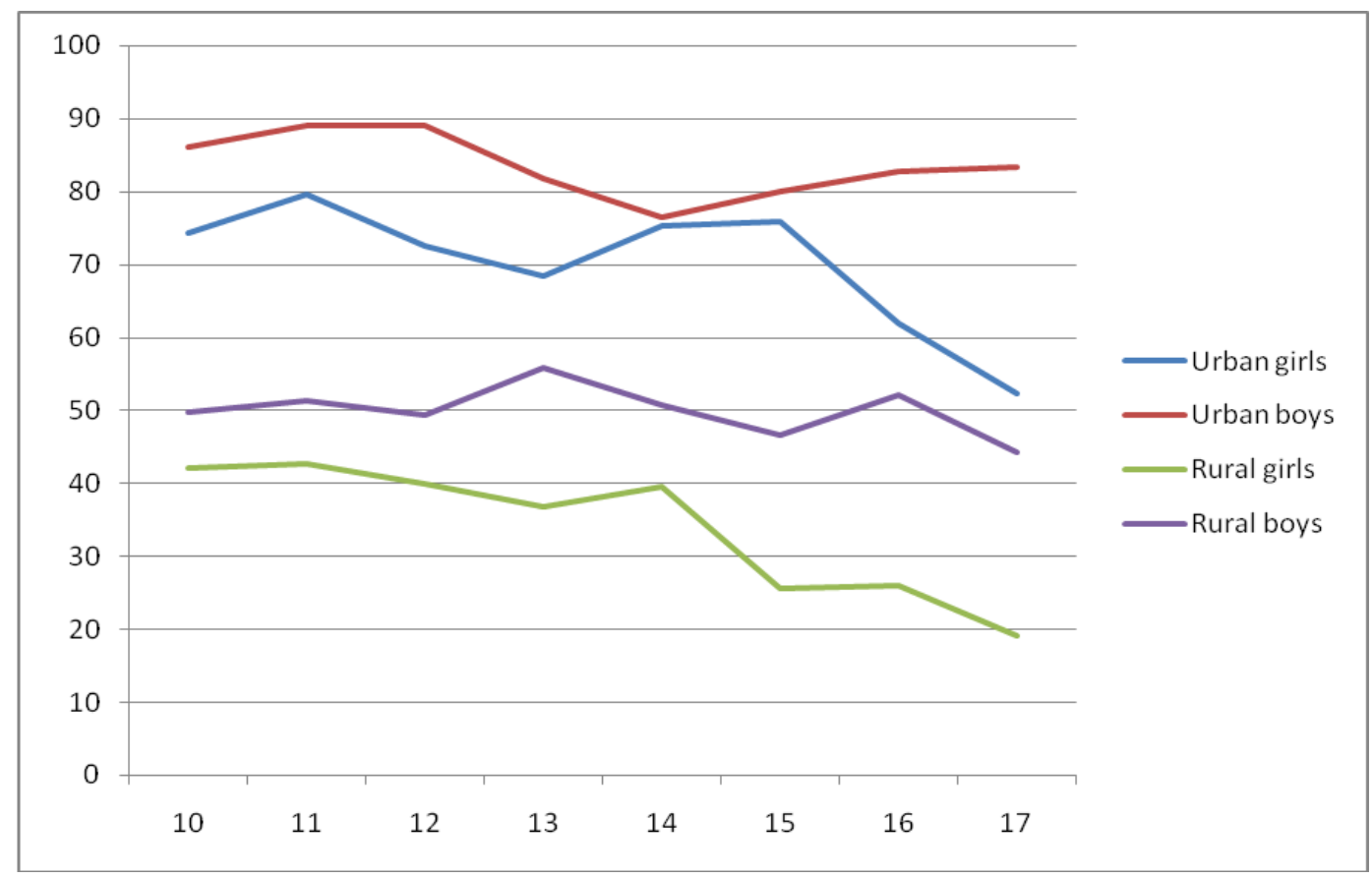

Table 8: Non-Enrollment among School-Age ${ }^{\text {a }}$ Children

\begin{tabular}{|c|c|c|c|}
\hline \multicolumn{3}{|c|}{ Percent of 7-19 year olds not in school } \\
\hline Region & Girls & Boys & $\begin{array}{c}\text { Girls to } \\
\text { boys } \\
\text { ratio }\end{array}$ \\
\hline Boké & 59.0 & 47.6 & 1.2 \\
\hline Conakry & 28.2 & 16.3 & 1.7 \\
\hline Faranah & 58.0 & 41.5 & 1.4 \\
\hline Kankan & 70.2 & 62.5 & 1.1 \\
\hline Kindia & 58.6 & 41.1 & 1.4 \\
\hline Labé & 63.1 & 52.4 & 1.2 \\
\hline Mamou & 65.2 & 48.1 & 1.4 \\
\hline N'Zérékoré & 53.1 & 40.7 & 1.3 \\
\hline Urban & 31.9 & 18.7 & 1.7 \\
\hline Rural & 66.7 & 53.8 & 1.2 \\
\hline National & $\mathbf{5 5 . 3}$ & $\mathbf{4 2 . 7}$ & 1.3 \\
\hline
\end{tabular}

Read the first column of data as "Percent of 7-19 year old girls not in school."

${ }^{\text {a }}$ School age as reported by UNESCO

${ }^{b}$ Not in school at time of survey or during year of survey. 
Map 2: School-Age Females Not in School

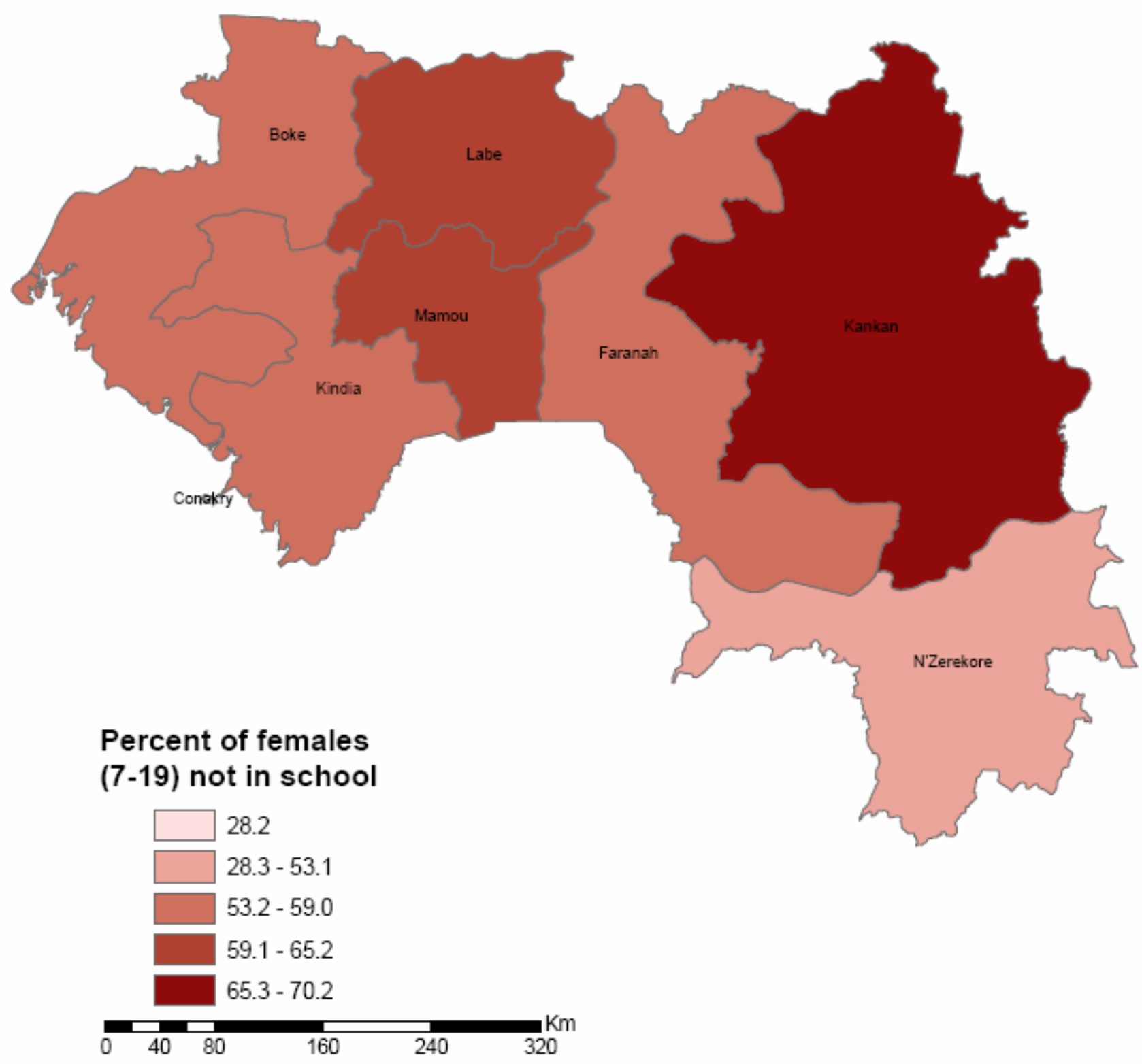


Table 9: Illiteracy among Females

\begin{tabular}{|c|c|c|}
\hline \multicolumn{3}{|c|}{$\begin{array}{c}\text { Percent of females who are illiterate } \\
\text { (unable to read a sentence) }\end{array}$} \\
\hline Region & $\begin{array}{c}15-19 \\
\text { year olds }\end{array}$ & $\begin{array}{c}20-24 \\
\text { year olds }\end{array}$ \\
\hline Boké & 71.0 & 86.2 \\
\hline Conakry & 36.5 & 55.5 \\
\hline Faranah & 67.9 & 87.3 \\
\hline Kankan & 80.0 & 91.2 \\
\hline Kindia & 68.3 & 80.8 \\
\hline Labé & 66.1 & 82.3 \\
\hline Mamou & 77.9 & 83.0 \\
\hline N'Zérékoré & 64.6 & 91.4 \\
\hline Urban & $\mathbf{3 9 . 0}$ & $\mathbf{6 1 . 4}$ \\
\hline Rural & $\mathbf{7 9 . 8}$ & $\mathbf{9 2 . 8}$ \\
\hline National & $\mathbf{6 3 . 8}$ & $\mathbf{8 0 . 6}$ \\
\hline
\end{tabular}

Read the first column of data as "Percent of 15-19 year old females who were unable to read a sentence provided during the survey." 
Map 3: Illiteracy among 15-19 Year Olds

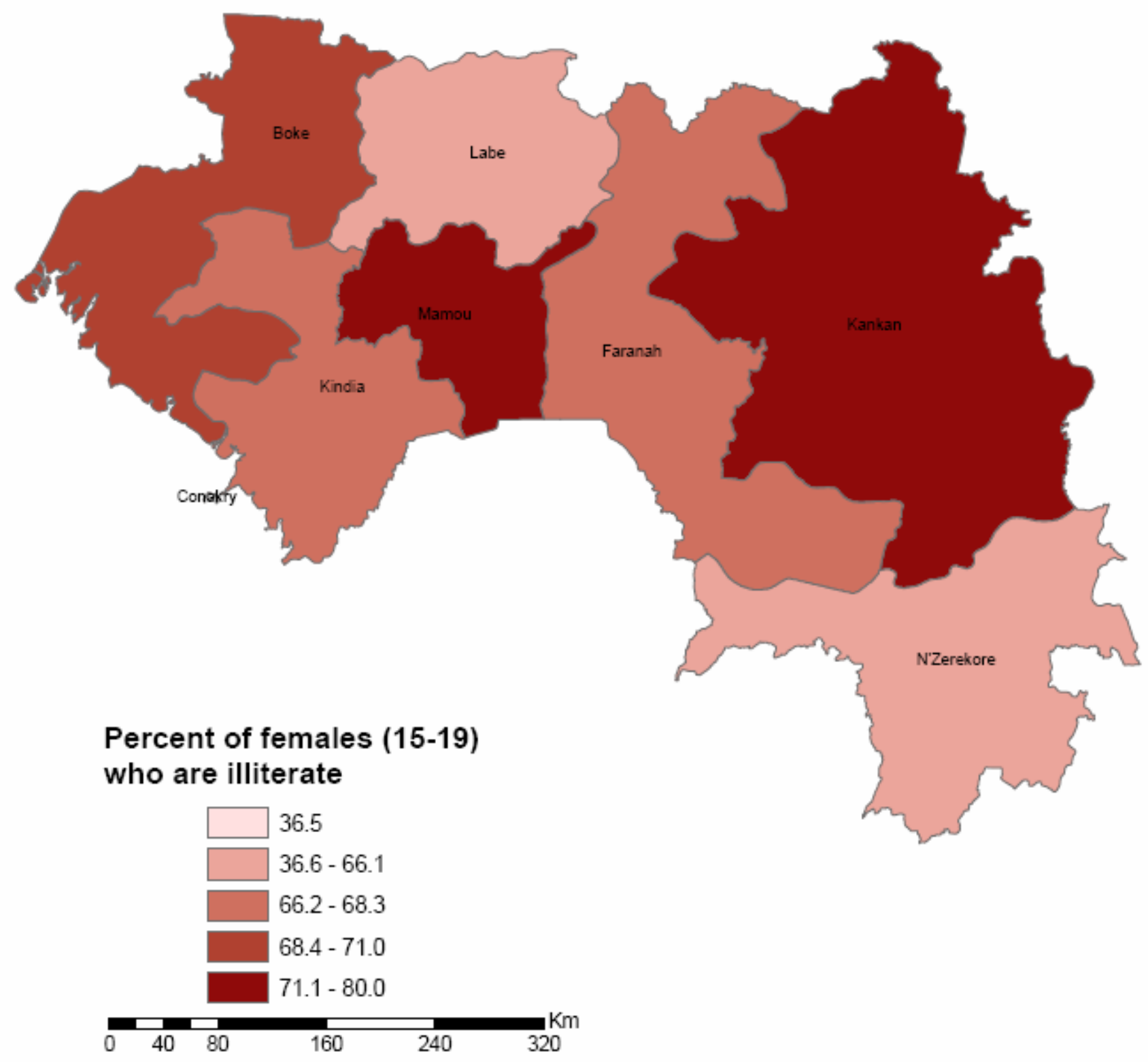




\section{The effects of low school attendance/achievement on reproductive health outcomes}

School attendance - regardless of other schooling measures such as school quality - is positive for both girls and boys. For girls, it has particularly strong reproductive health benefits. Girls who are in school during adolescence (even if they are not in the expected grade for their age) have lower rates of reported sexual activity than out-of-school peers. If sexually active, they are more likely to be able to negotiate for contraceptive protection and have lower rates of pregnancy. Where the data exist, it is useful to note the age at which girls typically become enrolled in school in large numbers (often at age 6 or later) and at what age certain segments of the adolescent population start leaving school. There are often markedly different trajectories for males and females and urban and rural residence; girls in rural areas typically have the lowest rates of school attendance and their dropout curves are often steeper and earlier than is the case for their male peers or urban females. There are at least four segments, data permitting, for policymakers and program designers to consider:

- girls who have never been in school,

- girls who are not currently in school but have some schooling,

- girls who are in school and in the expected grade for their age, and

- girls who are in school but significantly behind grade for age.

There are strong correlations between limited schooling - and other education-based indicators such as literacy - and early marriage. The age at first birth, overall fertility, and level of unmet need for contraception also vary significantly in most settings by the level of education of the female. 
Table 10: Illiteracy and Marriage before Age 15

\begin{tabular}{|c|c|c|}
\hline \multicolumn{3}{|c|}{$\begin{array}{c}\text { Percent of 15-24 year old females who are illiterate } \\
\text { (unable to read a sentence) }\end{array}$} \\
\hline Region & $\begin{array}{c}\text { Among those } \\
\text { married by age 15 }\end{array}$ & $\begin{array}{c}\text { Among the } \\
\text { never-married }\end{array}$ \\
\hline Boké & 90.1 & 59.9 \\
\hline Conakry & 67.4 & 30.4 \\
\hline Faranah & 95.2 & 47.7 \\
\hline Kankan & 98.6 & 59.5 \\
\hline Kindia & $(88.8)$ & 57.6 \\
\hline Labé & $(91.3)$ & 60.1 \\
\hline Mamou & $\mathbf{( 9 8 . 0 )}$ & 64.2 \\
\hline N'Zérékoré & 87.6 & 58.3 \\
\hline Urban & $\mathbf{6 6 . 8}$ & 34.4 \\
\hline Rural & $\mathbf{9 5 . 9}$ & $\mathbf{7 0 . 9}$ \\
\hline National & $\mathbf{8 8 . 5}$ & $\mathbf{5 2 . 1}$ \\
\hline
\end{tabular}

Read the first column of data as "Percent of 15-24 year old females married by age 15 who were unable to read a sentence provided during the survey."

Figures in parentheses are based on 25-50 unweighted cases.

Figure 8: Percent of Females 15-24 Who Are Illiterate, by Marital Status

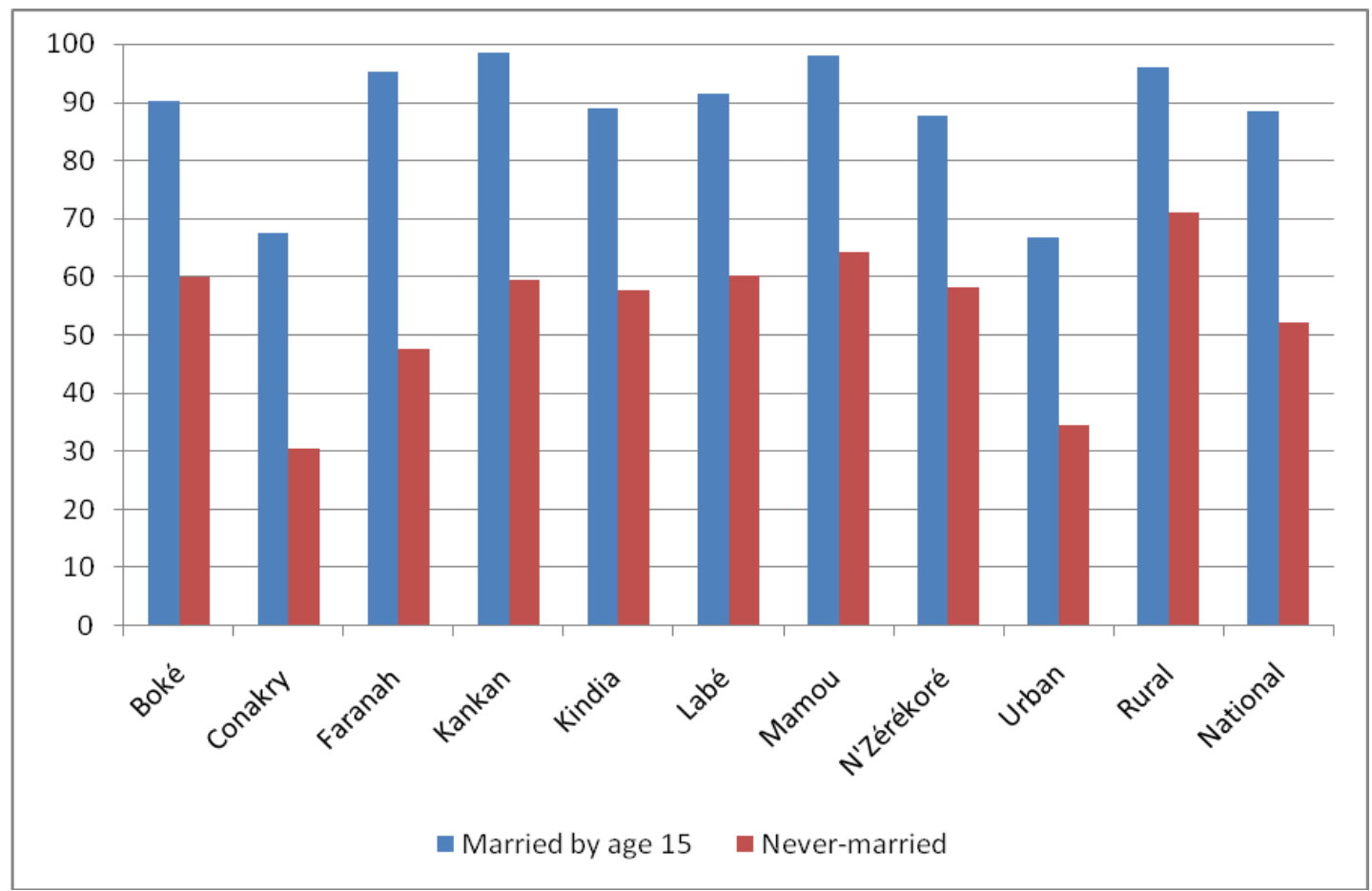


Table 11: School Enrollment, by Marital and Childbearing Status

\begin{tabular}{|c|c|c|c|c|}
\hline \multicolumn{6}{|c|}{ Percent of $\begin{array}{c}15-19 \text { year old females in school } \\
\text { and childbearing status }\end{array}$} \\
\hline \multirow{3}{*}{ Region } & $\begin{array}{c}\text { Ever- } \\
\text { married } \\
\text { with a } \\
\text { child }\end{array}$ & $\begin{array}{c}\text { Never- } \\
\text { married } \\
\text { with a } \\
\text { child }\end{array}$ & $\begin{array}{c}\text { Ever- } \\
\text { married, no } \\
\text { child }\end{array}$ & $\begin{array}{c}\text { Never- } \\
\text { married, no } \\
\text { child }\end{array}$ \\
\hline Urban & 13.3 & $(35.8)$ & 39.9 & 69.2 \\
\hline Rural & 6.3 & $(13.0)$ & 7.4 & 33.8 \\
\hline National & 7.8 & 22.8 & 16.9 & 50.9 \\
\hline
\end{tabular}

Read the first column of data as "Percent of ever-married 15-19 year old females with a child who were enrolled in school at the time of the survey."

Figures in parentheses are based on 25-50 unweighted cases.

${ }^{a}$ Enrolled during current school year

${ }^{b} \mathrm{~A}$ child who is living in the same household as the mother. 


\section{C - Context of Sexual Activity: Child Marriage, Gender Norms, and Reproductive Health}

Understanding the context of sexual initiation among young people and recognizing that girls may be particularly vulnerable to forced sexual encounters (both inside and outside of marriage) are critical to analyzing adolescent reproductive health outcomes. Both males and females are exploring their sexuality in the context of strong gender norms, and often within a framework of strong parental and peer pressures to engage (or not) in sex, to marry, and to bear children. These gender norms may sanction violence against women and other circumstances indicative of uneven power differentials in relationships. Such norms may play a key role in the level of information-about sexual and reproductive health and rights, for example-that is available to girls. Additionally, such norms may result in girls being subject to nonconsensual, unprotected sexual activity, both within and outside of marriage. This section presents data on the different contexts in which adolescent sexual activity occurs, and on selected reproductive health indicators.

\section{Child marriage and its associated risks}

In many countries, child marriage continues at significant levels, with exceptional concentrations in specific regions. "Cultural prescription" may be used falsely to justify marriage under age 18 and even under age 15, despite it's being illegal, as is true in many countries. Most countries are signatories to the Convention on the Elimination of All Forms of Discrimination Against Women and the Convention on the Rights of the Child, which confirm the rights of girls and boys to their childhood until the age of 18 . Despite favorable legal frameworks, young men's and, especially, women's access to vital sexual and reproductive health information and protection of their human rights may be undermined by cultural prescriptions, economic forces (as perceived by families), and gender norms. Sexual relations for young people of legal age should be fully voluntary, safe, and pleasurable. Thus, a great deal must be done in most settings to eliminate child marriage, economically motivated sexual relations, and the acceptance of violence within relationships. Further, much more must be done to increase access to the information needed to make informed and safe choices about reproductive health and life for children as they mature through adolescence.

Additionally, there is an important demographic consequence of the persistence of child marriage: short spans between generations, a key factor in population momentum and growth. Several factors conspire to increase childbearing among young brides. The bride's young age, often combined with the older age of her partner, intensifies power differentials in the relationship. Her young age is indicative of a relatively low level of education. Her lack of knowledge and skills may make her more reliant on high numbers of children for security within the marriage as well as long-term social security. It may further exaggerate the power imbalance between spouses and, thus, undermine the bride's ability to negotiate for sexual relations in which she is protected from STIs and HIV. These gender norms may prevent her from using contraception and other means to achieve her desired timing and spacing of children. 
Table 12: Age at First Marriage or Union

\begin{tabular}{|c|c|c|}
\hline \multicolumn{3}{|c|}{$\begin{array}{c}\text { Age at first marriage or union for 20-24 year old females } \\
\text { (percent) }\end{array}$} \\
\hline Region & $\begin{array}{c}\text { Married by } \\
\text { age } 15\end{array}$ & $\begin{array}{c}\text { Married by } \\
\text { age } 18\end{array}$ \\
\hline Boké & 34.3 & 61.6 \\
\hline Conakry & 15.4 & 47.3 \\
\hline Faranah & 26.7 & 71.5 \\
\hline Kankan & 28.0 & 76.3 \\
\hline Kindia & 11.5 & 65.9 \\
\hline Labé & 17.6 & 67.3 \\
\hline Mamou & 22.6 & 66.2 \\
\hline N'Zérékoré & 14.5 & 64.6 \\
\hline Urban & 14.0 & 44.5 \\
\hline Rural & $\mathbf{2 3 . 5}$ & $\mathbf{7 4 . 9}$ \\
\hline National & 19.8 & 63.1 \\
\hline
\end{tabular}

Read the first column of data as "Percent of 20-24 year old females married by age $15 . "$

Figure 9: Percent of 20-24 Year Old Females Who Were Married by Ages 15 and 18

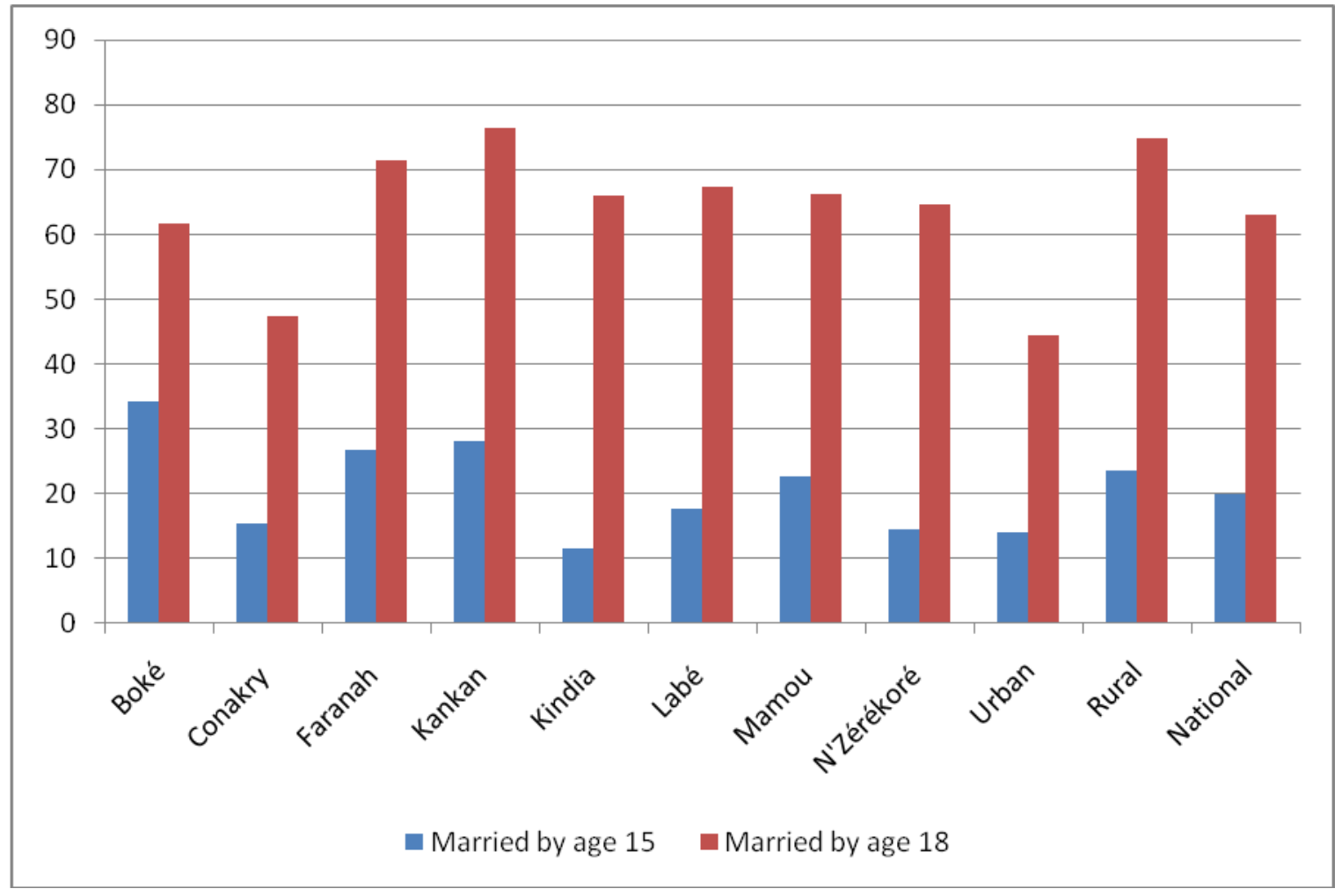


Map 4: Child Marriage among Females (20-24)

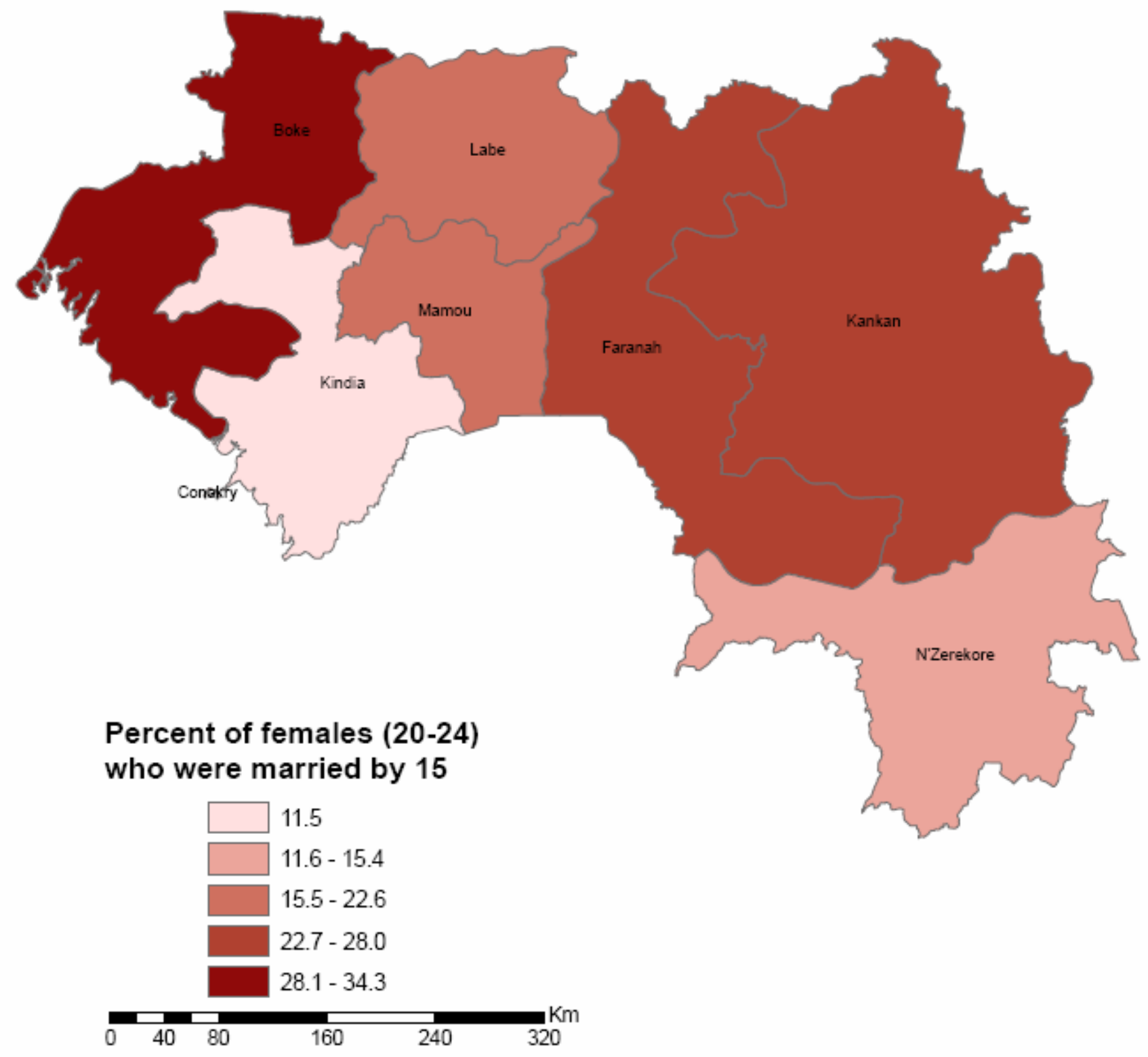




\section{Supporting pregnant girls and young mothers}

Young mothers, whether married or not, require social and health support. Married girls often have less mobility, less access to media, and less autonomy in decision making than married women. They are often isolated from their peers and at greater risk of gender-based violence than women who marry later. All these factors can constrain pregnant girls' access to information, services, and support. The youngest first-time mothers carry an elevated risk of maternal mortality and morbidity. Programmatic efforts centered on the youngest first-time mothers and first-time parents are beginning to demonstrate that targeted interventions encourage attended birth and HIV testing (and ideally sharing information with partners), as well as better infant feeding practices and child health care.

Table 13: Pregnancy and Childbearing

Percent of 15-19 year old females ever pregnant or had a child ${ }^{a}$

\begin{tabular}{|c|c|c|c|}
\hline Region & $\begin{array}{c}\text { Ever- }^{\text {married }}{ }^{\text {b }} \\
\text { Boké }\end{array}$ & $\begin{array}{c}\text { Never- } \\
\text { married }\end{array}$ & $\begin{array}{c}\text { All 15-19 } \\
\text { year old } \\
\text { females }\end{array}$ \\
\hline Conakry & 56.2 & 4.4 & 31.6 \\
\hline Faranah & 83.1 & 6.0 & 21.3 \\
\hline Kankan & 80.9 & 10.2 & 43.1 \\
\hline Kindia & 68.6 & 3.6 & 52.7 \\
\hline Labé & $(67.8)$ & 0.0 & 24.0 \\
\hline Mamou & 80.7 & 3.6 & 35.6 \\
\hline N'Zérékoré & 76.2 & 21.3 & 41.0 \\
\hline Urban & $\mathbf{6 6 . 3}$ & $\mathbf{8 . 3}$ & $\mathbf{2 2 . 5}$ \\
\hline Rural & $\mathbf{7 5 . 6}$ & $\mathbf{1 0 . 1}$ & $\mathbf{4 0 . 6}$ \\
\hline National & $\mathbf{7 3 . 2}$ & $\mathbf{9 . 3}$ & $\mathbf{3 3 . 5}$ \\
\hline
\end{tabular}

Read the first column of data as "Percent of ever-married 15-19 year old females who have ever been pregnant or had a child"

Figures in parentheses are based on 25-50 unweighted cases.

a Includes women who have had a child, are currently pregnant, have miscarried, or lost a child for other reasons.

${ }^{\mathrm{b}}$ Includes currently married, in union, separated, divorced, or widowed. 
Figure 10: Percent of 15-19 Year Old Females Ever Pregnant or Had a Child

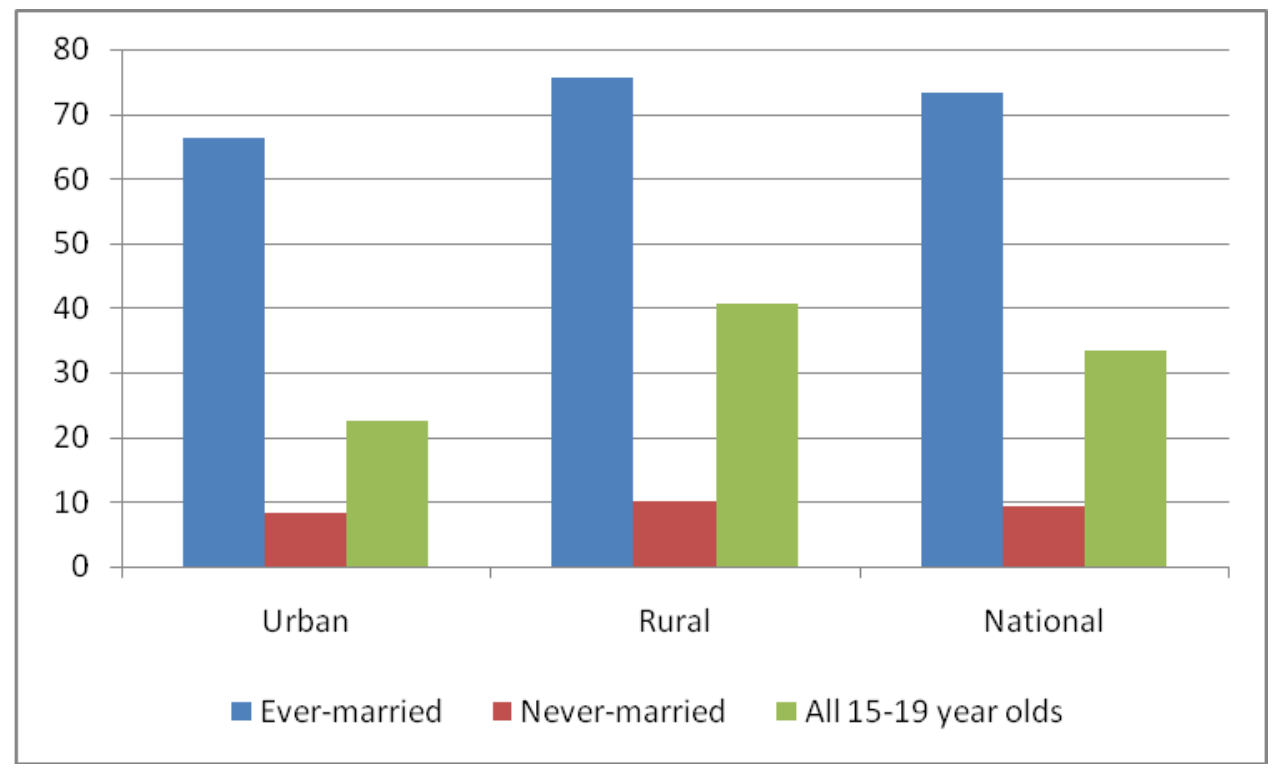




\section{The importance of addressing sexual activity both inside and outside of marriage}

It is critical to understand that there are two different circumstances in which young people have sexual relations: within the framework of marriage and outside of marriage. Though a rising share of sexual relations, including sexual initiation, is taking place outside of marriage, in most countries the majority of adolescent girls' sexual activity takes place within marriage. However, marriage is not a guarantee that sexual relations are safe, voluntary, or pleasurable. In some settings, married girls have a higher risk for sexually transmitted infections and HIV than their unmarried, sexually active peers. Married and unmarried sexually active adolescents need information, social support for informed decision making, and access to services and technologies to effectively maintain their sexual and reproductive health. In order to develop meaningful programs, it is vital to understand the nature of the partnerships and the context of these relationships. Although there is an overlap of needs, sexually active unmarried and married girls often require different services to ensure safe reproductive health due to their very different circumstances.

Table 14: Sexual Activity among 15-19 Year Old Females

\begin{tabular}{|c|c|c|c|c|c|c|}
\hline \multicolumn{7}{|c|}{ Sexual activity among $15-19$ year old females (percent) } \\
\hline \multirow{2}{*}{ Region } & \multicolumn{2}{|c|}{ Ever had sex } & \multicolumn{3}{|c|}{ Sexually active ${ }^{a}$} & \multirow{2}{*}{$\begin{array}{c}\text { Of sexually } \\
\text { active }^{\mathrm{a}} 15-19 \\
\text { year olds } \\
\text { Percent } \\
\text { married }\end{array}$} \\
\hline & $\begin{array}{l}\text { Never- } \\
\text { married }\end{array}$ & All & $\begin{array}{c}\text { Currently } \\
\text { married }\end{array}$ & $\begin{array}{l}\text { Never- } \\
\text { married }\end{array}$ & All & \\
\hline Boké & 29.5 & 57.5 & 45.3 & 9.0 & 22.2 & $(75.6)$ \\
\hline Conakry & 26.4 & 48.6 & 50.3 & 7.8 & 19.1 & $(71.5)$ \\
\hline Faranah & 32.0 & 62.7 & 52.9 & 9.7 & 28.6 & 81.5 \\
\hline Kankan & 41.0 & 75.5 & 50.4 & 23.9 & 38.7 & 74.3 \\
\hline Kindia & 21.4 & 46.1 & 55.1 & 12.5 & 25.5 & 66.4 \\
\hline Labé & 3.1 & 33.0 & (42.1) & 1.4 & 11.6 & $*$ \\
\hline Mamou & 6.5 & 45.2 & 42.0 & 0.0 & 16.8 & $(0.0)$ \\
\hline N'Zérékoré & 68.7 & 79.9 & 54.0 & 29.5 & 37.9 & 48.4 \\
\hline Urban & 34.3 & 50.4 & 51.0 & 13.9 & 22.1 & 50.8 \\
\hline Rural & 34.4 & 64.8 & 50.0 & 14.5 & 30.0 & 74.2 \\
\hline National & 34.4 & 59.1 & 50.3 & 14.2 & 26.8 & 66.6 \\
\hline
\end{tabular}

Read the first column of data as "Percent of never-married 15-19 year old females who ever had sex who are sexually active." (See footnote "a" below for definition of sexually active)

Figures in parentheses are based on 25-50 unweighted cases.

*Indicates that a figure is based on fewer than 25 unweighted cases and has been suppressed.

${ }^{a}$ Reported having sex within the four weeks preceding the survey 
Table 15: Sexual Initiation among 20-24 Year Old Females

\begin{tabular}{|c|c|c|c|}
\hline \multicolumn{4}{|c|}{ Sexual initiation among females currently aged 20-24 (percent) } \\
\hline Region & $\begin{array}{c}\text { Had sex by the } \\
\text { age of } 15\end{array}$ & $\begin{array}{c}\text { Had sex by the } \\
\text { age of } 18\end{array}$ & $\begin{array}{c}\text { First sexual } \\
\text { experience at } \\
\text { marriage }\end{array}$ \\
\hline Boké & 38.9 & 79.7 & 53.0 \\
\hline Conakry & 15.4 & 58.7 & 16.2 \\
\hline Faranah & 29.1 & 83.8 & 60.3 \\
\hline Kankan & 46.9 & 92.5 & 49.9 \\
\hline Kindia & 13.9 & 75.4 & 27.7 \\
\hline Labé & 22.4 & 68.5 & 53.8 \\
\hline Mamou & 25.5 & 71.0 & 61.7 \\
\hline N'Zérékoré & 22.6 & 79.7 & 58.4 \\
\hline Urban & $\mathbf{1 7 . 2}$ & $\mathbf{6 2 . 8}$ & $\mathbf{2 5 . 5}$ \\
\hline Rural & $\mathbf{3 0 . 5}$ & $\mathbf{8 3 . 3}$ & $\mathbf{5 6 . 1}$ \\
\hline National & $\mathbf{2 5 . 3}$ & $\mathbf{7 5 . 4}$ & $\mathbf{4 4 . 2}$ \\
\hline
\end{tabular}

Read the first column of data as "Percent of $20-24$ year old females who had sex by age $15 . "$

Figure 11: Sexual Initiation among 20-24 Year Old Females, by Region (percent)

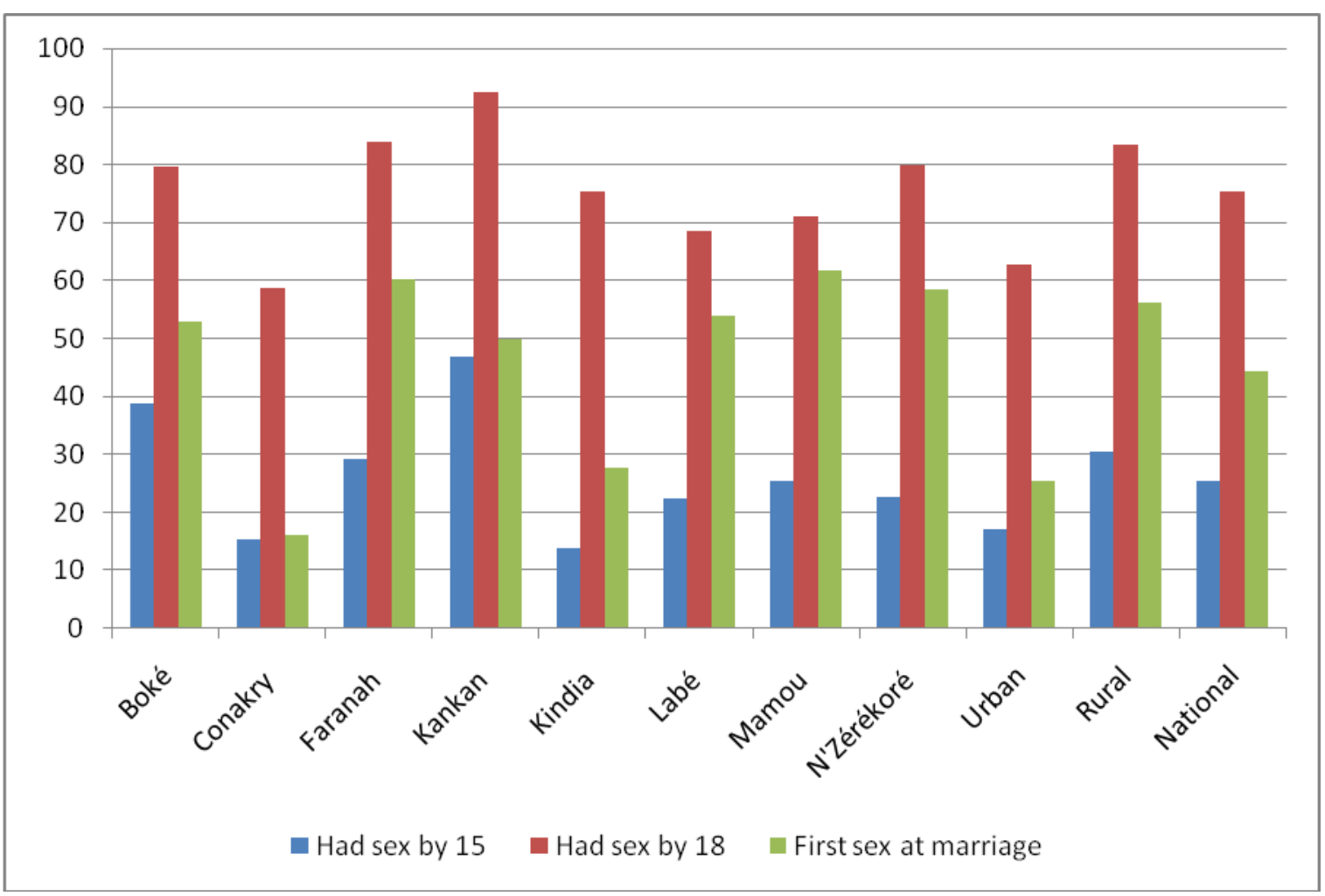


Table 16: Non-Consensual First Sex among 15-24 Year Old Females

\begin{tabular}{|c|c|}
\hline $\begin{array}{c}\text { Percent of 15-24 year old females who have } \\
\text { experienced forced sex }\end{array}$ & $\begin{array}{c}\text { All 15-24 year old } \\
\text { females } \\
\text { First time sex } \text { forced }\end{array}$ \\
\hline Bokion & 24.2 \\
\hline Conakry & 30.8 \\
\hline Faranah & 23.4 \\
\hline Kankan & 20.9 \\
\hline Kindia & 27.2 \\
\hline Labé & 43.0 \\
\hline Mamou & 39.5 \\
\hline N'Zérékoré & 6.9 \\
\hline Urban & $\mathbf{2 6 . 3}$ \\
\hline Rural & $\mathbf{2 0 . 4}$ \\
\hline National & $\mathbf{2 2 . 3}$ \\
\hline Read the first column of data as “Percent of 15-24 year old 15-24 \\
\hline $\begin{array}{l}\text { year old females whose first sex was forced." } \\
\text { Refers only to first sexual intercourse. }\end{array}$ \\
\hline
\end{tabular}

Figure 12: Percent of 15-24 Year Old Females Who Have Experienced Non-Consensual Sex

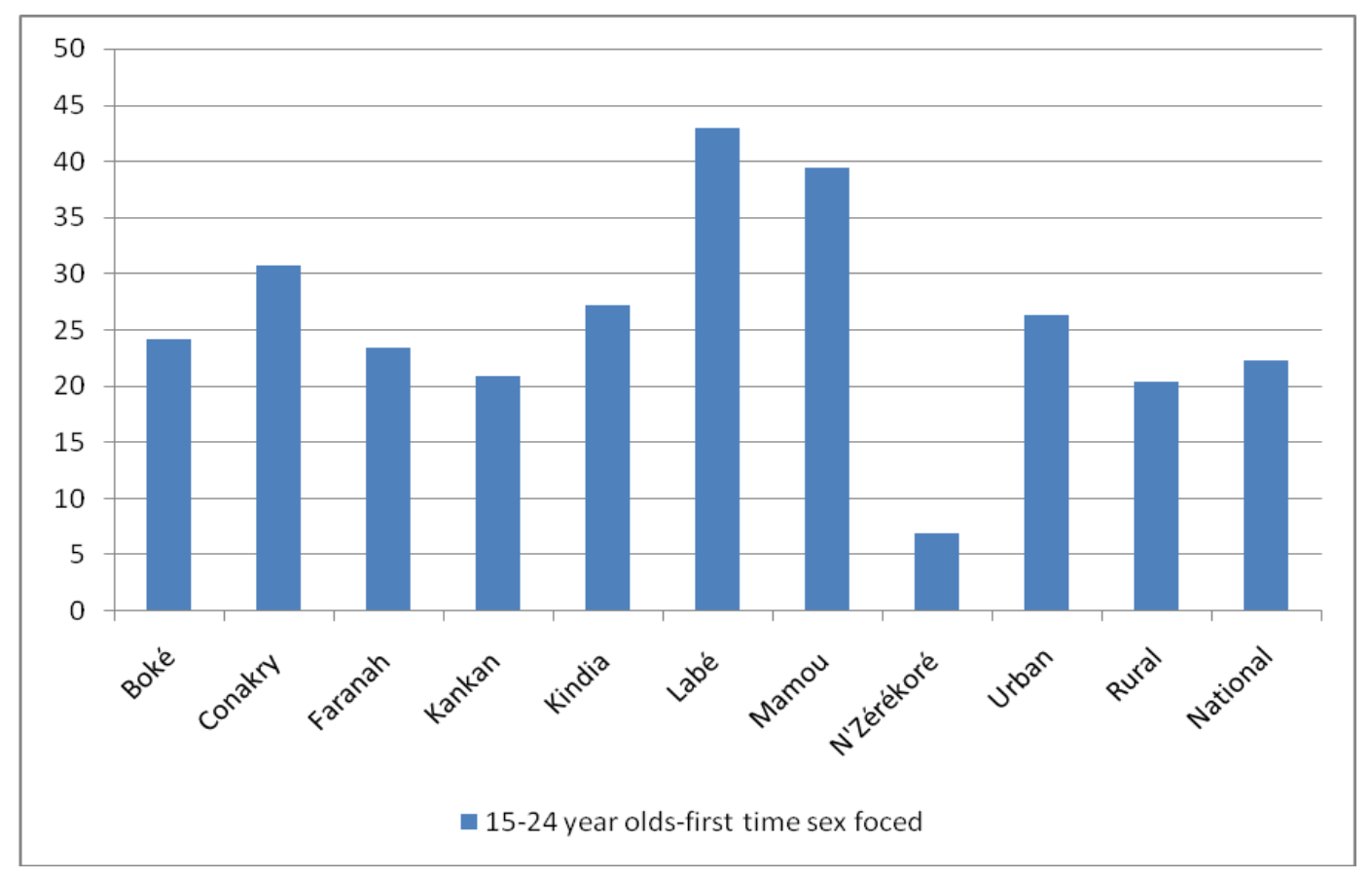




\section{Age difference between adolescent females and their partners}

For many brides in developing countries, the younger the age at marriage, the larger the age difference between the girl and her husband. On average, the husbands of married girls are older than the partners of sexually active unmarried girls. The age differential has two important dimensions:

- the age of the girl entering into the sexual relationship, which is related to her physical and emotional readiness; and

- the age of her partner, which is related to the extent of his previous sexual relations and, therefore, his exposure to STIs or HIV.

The large age gap between girls and their partners or husbands often puts these girls at a disadvantage in avoiding violence and in negotiating healthy sexual behavior. The age difference between partnerswhether married or not-has implications for the woman's ability to negotiate voluntary, safe, and protected sexual relations. Research shows that marriages between young women and older men are less equitable. ${ }^{8}$

Table 17: Age Difference between Partners at First Sex

\begin{tabular}{|c|c|c|c|}
\hline \multicolumn{5}{|c|}{$\begin{array}{c}\text { Age difference between woman and first sexual partner, among females } \\
\text { currently aged 15-24 (percent) }\end{array}$} \\
\hline Region & $\begin{array}{c}\text { Partner } \\
\text { younger/same } \\
\text { age as her }\end{array}$ & $\begin{array}{c}\text { Partner less } \\
\text { than 10 years } \\
\text { older }\end{array}$ & $\begin{array}{c}\text { Partner 10 or } \\
\text { more years } \\
\text { older }\end{array}$ \\
\hline Boké & 4.3 & 53.1 & 42.6 \\
\hline Conakry & 1.0 & 41.4 & 57.6 \\
\hline Faranah & 4.9 & 32.8 & 62.3 \\
\hline Kankan & 0.8 & 28.1 & 71.1 \\
\hline Kindia & 2.0 & 29.6 & 68.5 \\
\hline Labé & 0.0 & 13.2 & 86.9 \\
\hline Mamou & 0.0 & 25.1 & 74.9 \\
\hline N'Zérékoré & 8.9 & 65.4 & 25.7 \\
\hline Urban & $\mathbf{2 . 3}$ & $\mathbf{4 7 . 3}$ & $\mathbf{5 0 . 5}$ \\
\hline Rural & $\mathbf{4 . 8}$ & $\mathbf{4 1 . 0}$ & $\mathbf{5 4 . 2}$ \\
\hline National & $\mathbf{4 . 0}$ & $\mathbf{4 3 . 1}$ & $\mathbf{5 3 . 0}$ \\
\hline
\end{tabular}

Read the first column of data as "Percent of 15-24 year old females whose first sexual partner was the same age as she or younger."

\footnotetext{
${ }^{8}$ Clark, Shelley, Judith Bruce, and Annie Dude. 2006. "Protecting Young Women from HIV/AIDS: The Case Against Child and Adolescent Marriage," International Family Planning Perspectives, 32(2): 79-88.
} 
Table 18: Age Difference between Current Partners

\begin{tabular}{|c|c|c|c|}
\hline \multicolumn{4}{|c|}{$\begin{array}{c}\text { Age difference between woman and current husband/cohabiting partner, } \\
\text { among females aged 15-24 (percent) }\end{array}$} \\
\hline Region & $\begin{array}{c}\text { Partner } \\
\text { younger/same } \\
\text { age as her }\end{array}$ & $\begin{array}{c}\text { Partner less } \\
\text { than 10 years } \\
\text { older }\end{array}$ & $\begin{array}{c}\text { Partner 10 or } \\
\text { more years } \\
\text { older }\end{array}$ \\
\hline Boké & 0.4 & 25.8 & 73.8 \\
\hline Conakry & 0.8 & 33.8 & 65.4 \\
\hline Faranah & 0.4 & 38.0 & 61.6 \\
\hline Kankan & 0.9 & 34.7 & 64.4 \\
\hline Kindia & 0.6 & 33.2 & 66.2 \\
\hline Labé & 0.0 & 18.1 & 81.9 \\
\hline Mamou & 0.7 & 17.8 & 81.5 \\
\hline N'Zérékoré & 0.3 & 46.9 & 52.8 \\
\hline Urban & $\mathbf{0 . 6}$ & $\mathbf{2 9 . 4}$ & $\mathbf{6 9 . 9}$ \\
\hline Rural & $\mathbf{0 . 5}$ & $\mathbf{3 5 . 9}$ & $\mathbf{6 3 . 6}$ \\
\hline National & $\mathbf{0 . 5}$ & $\mathbf{3 4 . 1}$ & $\mathbf{6 5 . 4}$ \\
\hline
\end{tabular}

Read the first column of data as "Percent of 15-24 year old females with a husband/cohabiting partner the same age as she or younger." 


\section{Gender norms surrounding domestic violence}

All sexual relations take place within a social context. Gender norms affect both males' and females' perceptions of the acceptability of using violence to control girls' and women's mobility, decision making, and friendships, as well as the circumstances, timing of, and safety of sexual relations. Girls and boys often internalize these norms very early in life, laying a foundation for unequal sexual relations. There is a correlation between inequitable gender norms and the experience of violence. For example, women who agree that there are circumstances under which it is acceptable for a husband to beat his wife are more likely to report ever having experienced violence. ${ }^{9}$ Moreover, the adverse consequences of violence against women, including its association with unintended pregnancy and HIV infection, have been documented. Therefore, data on the acceptability of violence, when available, can be an important indicator to consider in developing effective sexual and reproductive health programs.

Table 19A: Female Attitudes toward Domestic Violence

\begin{tabular}{|c|c|c|c|}
\hline \multicolumn{3}{|c|}{$\begin{array}{c}\text { Percent of 15-24 year old females who think that wife beating is } \\
\text { completely justified }\end{array}$} \\
\hline Region & Ever-married & Never-married & $\begin{array}{c}\text { All 15-24 year } \\
\text { olds }\end{array}$ \\
\hline Boké & 19.6 & 24.3 & 21.5 \\
\hline Conakry & 12.2 & 9.1 & 10.7 \\
\hline Faranah & 34.2 & 31.1 & 33.4 \\
\hline Kankan & 37.5 & 48.2 & 39.8 \\
\hline Kindia & 40.0 & 36.3 & 38.5 \\
\hline Labé & 35.3 & 30.2 & 33.1 \\
\hline Mamou & 54.8 & 45.3 & 51.1 \\
\hline N'Zérékoré & 15.9 & 10.6 & 13.6 \\
\hline Urban & $\mathbf{1 8 . 5}$ & $\mathbf{1 7 . 0}$ & $\mathbf{1 7 . 7}$ \\
\hline Rural & $\mathbf{3 1 . 0}$ & $\mathbf{2 8 . 2}$ & $\mathbf{3 0 . 1}$ \\
\hline National & $\mathbf{2 7 . 4}$ & $\mathbf{2 2 . 5}$ & $\mathbf{2 5 . 5}$ \\
\hline
\end{tabular}

Read the first column of data as "Percent of 15-24 year old ever-married females who think that wife beating is completely justified."

a Women who answered yes to all of the following five questions: Wife beating is justified if 1) wife goes out without telling husband, 2) wife neglects children, 3) wife argues with husband, 4) wife refuses to have sex with husband, and 5) wife burns the food.

\footnotetext{
${ }^{9}$ UN Millennium Project. 2006. "Public Choices, Private Decisions: Sexual and Reproductive Health and the Millennium Development Goals." New York: UN Millennium Project.
} 
Table 19B: Female Attitudes toward Domestic Violence

\begin{tabular}{|c|c|c|c|c|c|c|}
\hline \multicolumn{2}{|c|}{ Percent of 15-24 year old females who think that wife beating is justified under certain conditions } \\
\hline Region & $\begin{array}{c}\text { If wife goes } \\
\text { out without } \\
\text { telling } \\
\text { husband }\end{array}$ & $\begin{array}{c}\text { If wife } \\
\text { neglects } \\
\text { kids }\end{array}$ & $\begin{array}{c}\text { If wife argues } \\
\text { with husband }\end{array}$ & $\begin{array}{c}\text { If wife } \\
\text { refuses to } \\
\text { have sex }\end{array}$ & $\begin{array}{c}\text { 保 wife burns } \\
\text { the food }\end{array}$ & $\begin{array}{c}\text { Percent who } \\
\text { said yes to } \\
\text { at least one } \\
\text { reason }\end{array}$ \\
\hline Boké & 86.4 & 73.4 & 51.6 & 54.9 & 27.8 & 96.3 \\
\hline Conakry & 69.7 & 67.1 & 37.5 & 48.1 & 25.1 & 87.5 \\
\hline Faranah & 68.9 & 66.5 & 63.2 & 52.1 & 36.9 & 80.2 \\
\hline Kankan & 86.9 & 77.8 & 66.1 & 79.0 & 45.0 & 91.8 \\
\hline Kindia & 79.1 & 86.5 & 65.8 & 64.7 & 46.4 & 94.8 \\
\hline Labé & 90.2 & 87.4 & 82.1 & 69.1 & 46.0 & 94.9 \\
\hline Mamou & 81.4 & 81.4 & 66.7 & 67.7 & 57.2 & 92.8 \\
\hline N'Zérékoré & 57.0 & 63.0 & 52.3 & 57.7 & 24.7 & 77.8 \\
\hline Urban & $\mathbf{7 4 . 2}$ & $\mathbf{7 2 . 4}$ & $\mathbf{4 6 . 7}$ & $\mathbf{5 3 . 2}$ & $\mathbf{2 7 . 7}$ & $\mathbf{8 7 . 8}$ \\
\hline Rural & $\mathbf{7 4 . 3}$ & $\mathbf{7 3 . 5}$ & $\mathbf{6 3 . 4}$ & $\mathbf{6 4 . 2}$ & $\mathbf{3 9 . 3}$ & $\mathbf{8 8 . 2}$ \\
\hline National & $\mathbf{7 4 . 2}$ & $\mathbf{7 3 . 1}$ & $\mathbf{5 7 . 0}$ & $\mathbf{6 0 . 1}$ & $\mathbf{3 4 . 9}$ & $\mathbf{8 8 . 1}$ \\
\hline
\end{tabular}

Read the first column of data as "Percent of 15-24 year old females who think that wife beating is completely justified if the wife goes out without telling her husband."

${ }^{a}$ Females aged 15-24 who answered yes to any of the five questions detailed in the earlier columns.

Figure 13: Percent of 15-24 Year Old Females Who Think that Wife Beating is Justified under Certain Conditions

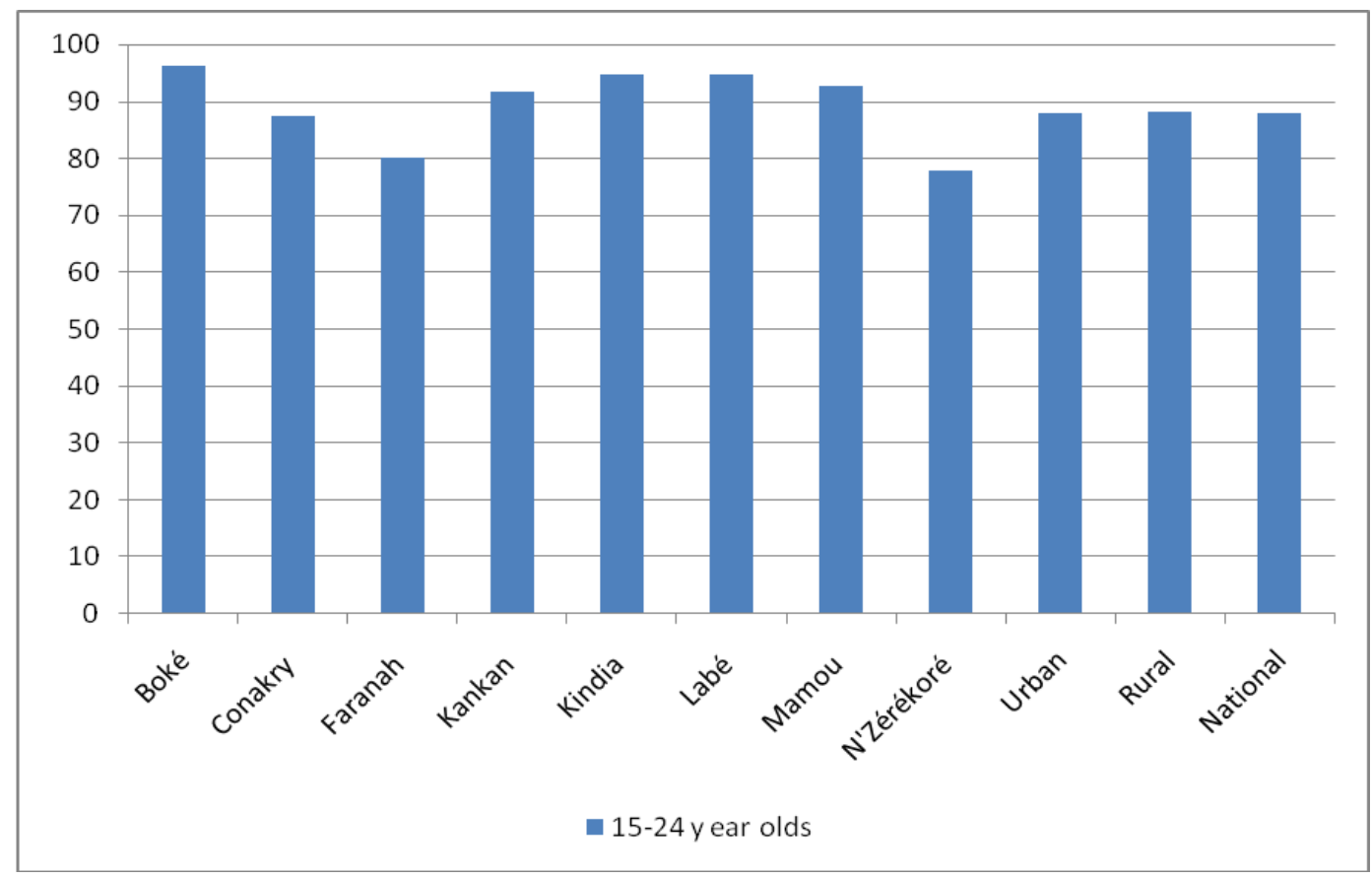




\section{An increasingly young and female HIV epidemic}

In many regions of the world, HIV infection has become increasingly more prevalent among young people, especially females. In sub-Saharan Africa, young women have become the new face of the disease. The threat is particularly acute among young women and girls with limited social and economic assets who are unable to avoid, manage, or leave unsafe sexual relationships, whether inside or outside of marriage. ${ }^{10}$ Analysis of DHS data from 31 countries shows that the majority of sexually active girls aged 15-19 in developing countries is married. ${ }^{11}$ Child marriage, though sometimes justified as a protection, is not safe and, in fact, may elevate the risk of HIV infection for young females. Young women are particularly disadvantaged since they are under pressure to become pregnant; contraception, therefore, is not presented as an option. Open communication between partners is very important to minimizing exposure to HIV. However, because of the gender-based inequalities present in many marriages and sexual relationships, women, especially girls, may find it difficult to communicate about HIV and negotiate condom use with their partners. So, while knowledge of and access to HIV testing and other services are important, they are not sufficient to ensure HIV prevention. Serious efforts must be made to reach vulnerable girls and strengthen their ability to protect themselves.

Table 20: HIV Testing

\begin{tabular}{|c|c|c|c|c|c|c|}
\hline \multirow{2}{*}{ HIV testing among females aged 15-24 } \\
\hline \multirow{2}{*}{ Region } & \multicolumn{2}{|c|}{$\begin{array}{c}\text { Percent ever had an } \\
\text { HIV test }\end{array}$} & $\begin{array}{c}\text { Percent tested in last } \\
12 \text { months }\end{array}$ & \multicolumn{2}{c|}{$\begin{array}{c}\text { Percent ever tested } \\
\text { AND received results }\end{array}$} \\
\cline { 2 - 7 } & $\begin{array}{c}15-19 \\
\text { year olds }\end{array}$ & $\begin{array}{c}20-24 \\
\text { year olds }\end{array}$ & $\begin{array}{c}15-19 \\
\text { year olds }\end{array}$ & $\begin{array}{c}20-24 \\
\text { year olds }\end{array}$ & $\begin{array}{c}15-19 \\
\text { year olds }\end{array}$ & $\begin{array}{c}20-24 \\
\text { year olds }\end{array}$ \\
\hline Boké & 1.5 & 1.7 & 1.0 & 1.7 & 1.5 & 1.7 \\
\hline Conakry & 3.2 & 6.7 & 1.9 & 2.7 & 1.5 & 5.8 \\
\hline Faranah & 0.5 & 0.0 & 0.0 & 0.0 & 0.5 & 0.0 \\
\hline Kankan & 1.4 & 0.0 & 0.8 & 0.0 & 1.0 & 0.0 \\
\hline Kindia & 0.6 & 4.0 & 0.6 & 1.3 & 0.6 & 4.0 \\
\hline Labé & 4.0 & 5.7 & 4.0 & 1.9 & 4.0 & 4.9 \\
\hline Mamou & 1.2 & 1.4 & 1.2 & 0.0 & 1.2 & 1.4 \\
\hline N'Zérékoré & 3.2 & 4.3 & 2.5 & 2.4 & 3.2 & 4.3 \\
\hline Urban & $\mathbf{3 . 7}$ & $\mathbf{6 . 7}$ & $\mathbf{2 . 7}$ & $\mathbf{3 . 1}$ & $\mathbf{3 . 0}$ & $\mathbf{6 . 3}$ \\
\hline Rural & $\mathbf{1 . 1}$ & $\mathbf{1 . 5}$ & $\mathbf{1 . 0}$ & $\mathbf{0 . 7}$ & $\mathbf{1 . 0}$ & $\mathbf{1 . 4}$ \\
\hline National & $\mathbf{2 . 2}$ & $\mathbf{3 . 5}$ & $\mathbf{1 . 6}$ & $\mathbf{1 . 6}$ & $\mathbf{1 . 8}$ & $\mathbf{3 . 3}$ \\
\hline
\end{tabular}

Read the first column of data as "Percent of 15-19 year females who ever had an HIV test."

\footnotetext{
${ }^{10}$ Bruce, Judith. 2007. "Girls left behind: Redirecting HIV interventions toward the most vulnerable." Transitions to Adulthood Brief no. 23. New York: Population Council.

${ }^{11}$ Bruce, Judith and Shelley Clark. 2003. "Including Married Adolescents in Adolescent Reproductive Health and HIV/AIDS Policy," background paper prepared for the WHO/UNFPA/Population Council Technical Consultation on Married Adolescents, Geneva: 9-12 December.
} 
Figure 14: Percent of 15-24 Year Old Females Who Have Ever Had an HIV Test in the Past 12 Months

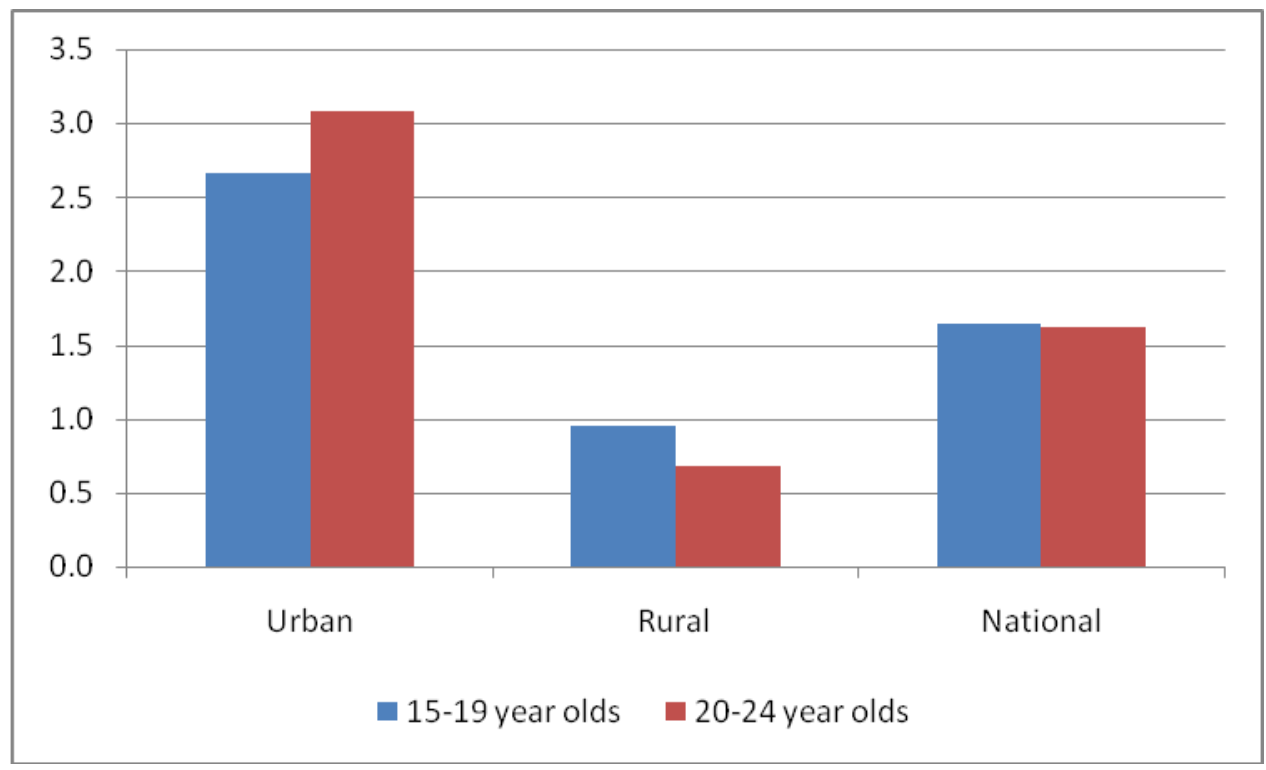

Table 21: Knowledge of HIV Prevention Methods

\begin{tabular}{|c|c|c|c|}
\hline \multicolumn{3}{|c|}{$\begin{array}{c}\text { Knowledge of methods to reduce the risk of AIDS, } \\
\text { among females aged 15-24 (percent) }\end{array}$} \\
\hline Region & Use condom & $\begin{array}{c}\text { Limit sex to } \\
\text { one } \\
\text { uninfected } \\
\text { partner }\end{array}$ & $\begin{array}{c}\text { Abstain from } \\
\text { sex }\end{array}$ \\
\hline Boké & 69.7 & 75.6 & 67.2 \\
\hline Conakry & 77.7 & 82.2 & 82.5 \\
\hline Faranah & 74.4 & 93.0 & 93.3 \\
\hline Kankan & 84.2 & 93.7 & 90.6 \\
\hline Kindia & 86.4 & 96.6 & 90.0 \\
\hline Labé & 70.9 & 89.4 & 88.4 \\
\hline Mamou & 65.2 & 85.2 & 73.7 \\
\hline N'Zérékoré & 76.1 & 93.4 & 92.5 \\
\hline Urban & $\mathbf{8 0 . 6}$ & $\mathbf{8 7 . 3}$ & $\mathbf{8 5 . 8}$ \\
\hline Rural & $\mathbf{7 4 . 3}$ & $\mathbf{9 0 . 0}$ & $\mathbf{8 6 . 0}$ \\
\hline National & $\mathbf{7 6 . 8}$ & $\mathbf{8 8 . 9}$ & $\mathbf{8 5 . 9}$ \\
\hline
\end{tabular}

Read the first column of data as "Percent of 15-24 year old females who know that using a condom is a method to reduce the risk of AIDS." 


\section{Contraceptive choice and safety}

Ensuring contraceptive choice and safety is crucial to ensuring adolescent sexual and reproductive health. Lack of access to or use of modern contraceptives is a major cause of unintended pregnancies. Adolescents, assuming they know that contraceptives are an option, have a significantly higher unmet need for modern contraception than the general population. An analysis of DHS data from 31 countries found that, on average, 80 percent of unprotected sexual encounters among girls occurred within marriage. On average, in the 25 countries where data were available, 56.7 percent of married 15-19 year old girls had unprotected sex the previous week, while among their unmarried sexually active peers the rate was 14.2 percent. ${ }^{12}$ Although the reason that more than half of the married girls had unprotected sex is not clear, it is likely due to complex, sensitive issues ranging from the desire to get pregnant to the inability to negotiate safe reproductive health practices within the relationship. Because of their young age, both married and unmarried girls and young women may be at a significant disadvantage in knowing about or having the social authority to negotiate contraceptive use, especially within the power dynamic of a relationship with a more economically secure, often older, partner. Their limited negotiating power for male and female condom use puts many adolescent girls at risk of STIs and HIV as well as unintended pregnancy.

\footnotetext{
${ }^{12}$ Ibid.
} 
Table 22: Female Attitudes towards Male Condom Use

\begin{tabular}{|c|c|c|c|c|}
\hline $\begin{array}{c}\text { Percent of females aged 15-24 who said a woman can ask husband to } \\
\text { use condom if he has an STD }\end{array}$ \\
\hline \multirow{2}{*}{ Region } & \multicolumn{3}{|c|}{ Ever-married } & \multicolumn{2}{c|}{ Never-married } \\
\cline { 2 - 5 } & $\begin{array}{c}15-19 \\
\text { year olds }\end{array}$ & $\begin{array}{c}20-24 \\
\text { year olds }\end{array}$ & $\begin{array}{c}15-19 \\
\text { year olds }\end{array}$ & $\begin{array}{c}20-24 \\
\text { year olds }\end{array}$ \\
\hline Boké & 66.9 & 64.7 & 71.9 & $*$ \\
\hline Conakry & 84.8 & 83.1 & 86.4 & 87.6 \\
\hline Faranah & 52.0 & 59.5 & 69.5 & $*$ \\
\hline Kankan & 75.9 & 71.8 & 92.9 & $*$ \\
\hline Kindia & 79.9 & 80.4 & 87.2 & $(100.0)$ \\
\hline Labé & $(71.1)$ & 60.0 & 76.5 & $*$ \\
\hline Mamou & $(35.3)$ & 58.7 & 57.3 & $*$ \\
\hline N'Zérékoré & 71.2 & 69.8 & 84.4 & $(84.3)$ \\
\hline Urban & $\mathbf{8 3 . 2}$ & $\mathbf{7 8 . 3}$ & $\mathbf{8 6 . 6}$ & $\mathbf{9 0 . 8}$ \\
\hline Rural & $\mathbf{6 6 . 5}$ & $\mathbf{6 7 . 5}$ & $\mathbf{7 5 . 7}$ & $\mathbf{6 5 . 5}$ \\
\hline National & $\mathbf{7 0 . 7}$ & $\mathbf{7 0 . 9}$ & $\mathbf{8 1 . 1}$ & $\mathbf{8 2 . 8}$ \\
\hline
\end{tabular}

Read the first column of data as "Percent of ever-married 15-19 year old females who said a woman can ask her husband to use a condom if he has an STD."

Figures in parentheses are based on 25-50 unweighted cases.

*Indicates that a figure is based on fewer than 25 unweighted cases and has been suppressed. 
Table 23: Condom Use

\begin{tabular}{|c|c|c|c|c|}
\hline \multicolumn{5}{|c|}{ Percent of females aged $15-24^{a}$ who used a condom at last sex } \\
\hline \multirow{2}{*}{ Region } & \multicolumn{2}{|c|}{$\begin{array}{l}\text { Currently married or in } \\
\text { union }\end{array}$} & \multirow{2}{*}{$\begin{array}{l}\text { Never - } \\
\text { married }\end{array}$} & \multirow{2}{*}{$\begin{array}{l}\text { All } 15-24 \\
\text { year olds }\end{array}$} \\
\hline & Has a child & No child & & \\
\hline Boké & 0.0 & 5.2 & 7.8 & 4.4 \\
\hline Conakry & 11.1 & 18.4 & 50.8 & 25.1 \\
\hline Faranah & 1.6 & $(2.5)$ & $(44.7)$ & 10.9 \\
\hline Kankan & 3.2 & 0.0 & 14.6 & 4.2 \\
\hline Kindia & 3.0 & (4.5) & $(46.5)$ & 14.2 \\
\hline Labé & $(1.3)$ & $(0.0)$ & $*$ & 2.4 \\
\hline Mamou & $(0.0)$ & (4.5) & $*$ & 3.2 \\
\hline N'Zérékoré & 0.0 & 0.7 & 16.4 & 7.2 \\
\hline Urban & 6.4 & 15.8 & 35.7 & 21.7 \\
\hline Rural & 1.5 & 0.4 & 14.4 & 3.7 \\
\hline National & 2.7 & 5.7 & 25.9 & 10.2 \\
\hline \multicolumn{5}{|c|}{$\begin{array}{l}\text { Read the first column of data as "Percent of } 15-24 \text { year old married or in union females with at least one chil } \\
\text { who used a condom at last sex." }\end{array}$} \\
\hline
\end{tabular}

Figure 15: Percent of 15-24 Year Old Females Who Used a Condom at Last Sex

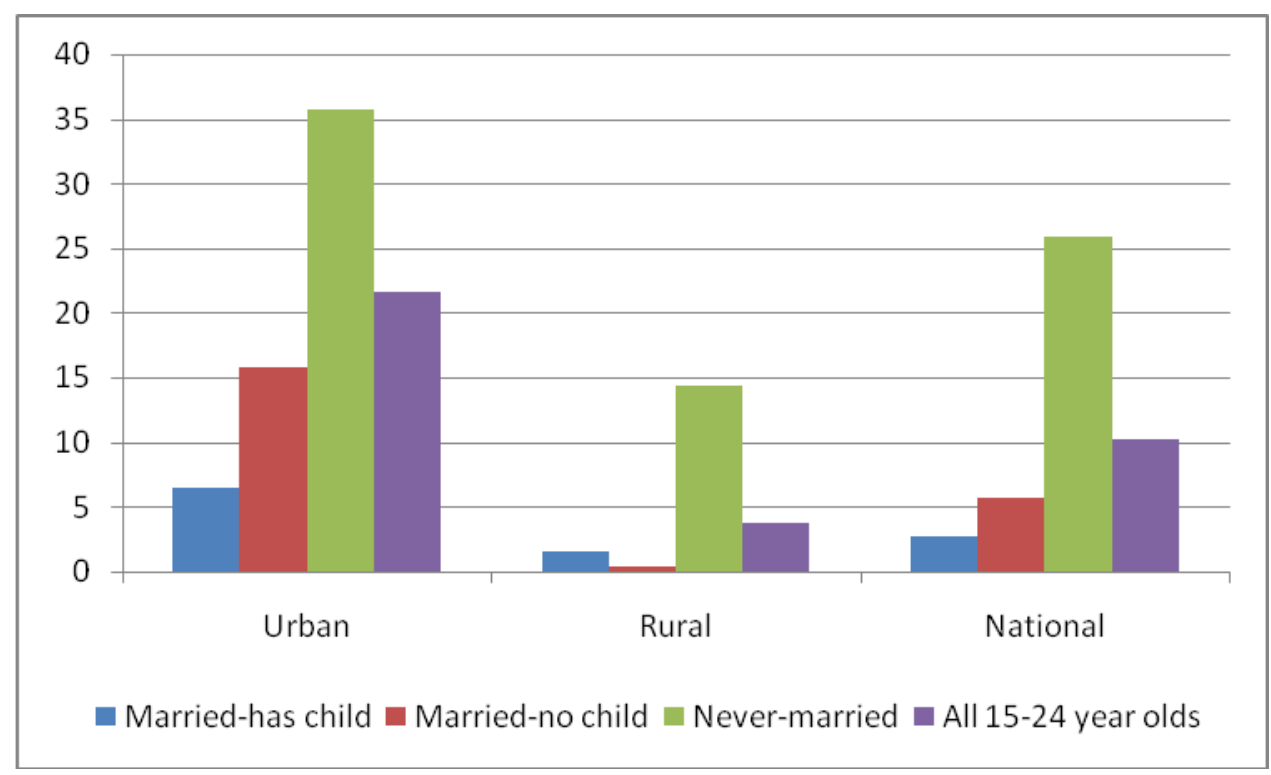


Table 24: Contraceptive Use

\begin{tabular}{|c|c|c|c|c|}
\hline \multicolumn{4}{|c|}{$\begin{array}{c}\text { Percent of females aged 15-24 } \\
\text { contraception }\end{array}$} \\
\hline \multirow{2}{*}{ Region } & $\begin{array}{c}\text { Used a modern } \\
\text { method }\end{array}$ & \multicolumn{2}{c|}{$\begin{array}{c}\text { Never used any } \\
\text { method }\end{array}$} \\
\cline { 2 - 5 } & $\begin{array}{c}\text { Ever- } \\
\text { married }\end{array}$ & $\begin{array}{c}\text { Never- } \\
\text { married }\end{array}$ & $\begin{array}{c}\text { Ever- } \\
\text { married }\end{array}$ & $\begin{array}{c}\text { Never- } \\
\text { married }\end{array}$ \\
\hline Boké & 9.4 & 19.4 & 89.1 & 79.1 \\
\hline Conakry & 35.5 & 51.0 & 59.7 & 40.6 \\
\hline Faranah & 20.1 & 54.5 & 54.3 & 33.8 \\
\hline Kankan & 14.5 & 43.0 & 74.5 & 54.8 \\
\hline Kindia & 6.6 & 47.0 & 89.0 & 43.5 \\
\hline Labé & 8.0 & $*$ & 90.6 & $*$ \\
\hline Mamou & 3.4 & $*$ & 94.5 & $*$ \\
\hline N'Zérékoré & 14.2 & 24.4 & 84.6 & 65.1 \\
\hline Urban & $\mathbf{2 9 . 6}$ & $\mathbf{4 5 . 0}$ & $\mathbf{6 6 . 3}$ & $\mathbf{4 7 . 9}$ \\
\hline Rural & $\mathbf{9 . 9}$ & $\mathbf{2 3 . 3}$ & $\mathbf{8 3 . 3}$ & $\mathbf{6 7 . 1}$ \\
\hline National & $\mathbf{1 5 . 6}$ & $\mathbf{3 5 . 0}$ & $\mathbf{7 8 . 4}$ & $\mathbf{5 6 . 8}$ \\
\hline
\end{tabular}

Read the first column of data as "Percent of ever-married 15-24 year old females who ever used a modern method of contraception."

*Indicates that a figure is based on fewer than 25 unweighted cases and has been suppressed.

${ }^{\mathrm{a}}$ Females aged 15-24 who reported having had sex. 


\section{Antenatal care and delivery assistance}

Young women in the developing world face great challenges during pregnancy and childbearing. The common, well-documented deficiencies in health services - in particular in the area of maternal health leave many mothers at very high risk. Young, first-time mothers, especially those who are poor and uneducated, are at increased risk of neonatal and infant death along with the threats to their own health. This risk becomes particularly acute when the mother is very young and her body may not be completely ready for childbearing. Access to appropriate maternal health services is critical for positive maternal and infant outcomes. These services can also play an important role in identifying and, if possible, treating STIs and HIV. Policymakers and program designers must ensure that girls have a healthy transition into motherhood, and this requires the provision of accessible, appropriate, and targeted reproductive health care services that have components tailored to young, first-time mothers.

Table 25: Antenatal Care

\begin{tabular}{|c|c|c|}
\hline \multicolumn{3}{|c|}{$\begin{array}{c}\text { Mean number of antenatal care visits } \\
\text { a } \\
\text { among females aged 15-24 }\end{array}$} \\
\hline Region & $\begin{array}{c}15-19 \\
\text { year olds }\end{array}$ & $\begin{array}{c}20-24 \\
\text { year olds }\end{array}$ \\
\hline Boké & 3.2 & 4.2 \\
\hline Conakry & 6.4 & 6.8 \\
\hline Faranah & 3.8 & 3.9 \\
\hline Kankan & 2.8 & 3.2 \\
\hline Kindia & 3.8 & 3.6 \\
\hline Labé & $(4.5)$ & 3.7 \\
\hline Mamou & 3.3 & $(3.6)$ \\
\hline N'Zérékoré & 3.9 & 3.5 \\
\hline Urban & $\mathbf{5 . 4}$ & $\mathbf{5 . 3}$ \\
\hline Rural & $\mathbf{3 . 4}$ & $\mathbf{3 . 5}$ \\
\hline National & $\mathbf{3 . 9}$ & $\mathbf{3 . 9}$ \\
\hline
\end{tabular}

Read the first column of data as "Mean number of Antenatal care visits among 15-19 year old females." Figures in parentheses are based on 25-50 unweighted cases.

${ }^{\mathrm{a}}$ For their most recent birth in the five years preceding the survey 
Table 26: Delivery Assistance

\begin{tabular}{|c|c|c|c|c|c|c|c|c|}
\hline \multicolumn{9}{|c|}{ Percent of women aged 15-24 who received delivery assistance ${ }^{a}$ of various types } \\
\hline \multirow[b]{2}{*}{ Region } & \multicolumn{2}{|c|}{$\begin{array}{c}\text { Health } \\
\text { professional }\end{array}$} & \multicolumn{2}{|c|}{$\begin{array}{l}\text { Traditional birth } \\
\text { attendant }\end{array}$} & \multicolumn{2}{|c|}{ Other $^{b}$} & \multicolumn{2}{|c|}{ No assistance } \\
\hline & $\begin{array}{c}\text { 15-19 } \\
\text { year } \\
\text { olds }\end{array}$ & $\begin{array}{c}\text { 20-24 } \\
\text { year } \\
\text { olds }\end{array}$ & $\begin{array}{c}\text { 15-19 } \\
\text { year } \\
\text { olds }\end{array}$ & $\begin{array}{c}\text { 20-24 } \\
\text { year } \\
\text { olds }\end{array}$ & $\begin{array}{c}\text { 15-19 } \\
\text { year } \\
\text { olds }\end{array}$ & $\begin{array}{c}\text { 20-24 } \\
\text { year } \\
\text { olds }\end{array}$ & $\begin{array}{c}\text { 15-19 } \\
\text { year } \\
\text { olds }\end{array}$ & $\begin{array}{c}\text { 20-24 } \\
\text { year } \\
\text { olds }\end{array}$ \\
\hline Boké & 25.6 & 35.4 & 21.2 & 20.8 & 38.9 & 37.9 & 14.3 & 6.0 \\
\hline Conakry & 93.5 & 91.9 & 4.2 & 3.5 & 2.3 & 4.6 & 0.0 & 0.0 \\
\hline Faranah & 31.6 & 37.7 & 20.6 & 16.1 & 47.8 & 46.2 & 0.0 & 0.0 \\
\hline Kankan & 44.1 & 35.7 & 27.2 & 27.8 & 28.7 & 26.0 & 0.0 & 10.5 \\
\hline Kindia & 23.9 & 29.3 & 28.5 & 26.8 & 45.8 & 38.9 & 1.8 & 5.1 \\
\hline Labé & $(44.6)$ & 27.5 & $(0.0)$ & 1.2 & (51.7) & 46.5 & (3.8) & 24.8 \\
\hline Mamou & 28.9 & (34.3) & 0.0 & $(6.4)$ & 71.1 & (46.4) & 0.0 & (12.9) \\
\hline N'Zérékoré & 45.1 & 50.8 & 42.2 & 32.2 & 7.0 & 13.6 & 5.6 & 3.4 \\
\hline Urban & 82.6 & 84.3 & 9.8 & 4.7 & 7.6 & 9.2 & 0.0 & 1.8 \\
\hline Rural & 29.9 & 29.8 & 29.0 & 26.3 & 36.5 & 35.3 & 4.6 & 8.6 \\
\hline National & 44.3 & 44.2 & 23.7 & 20.6 & 28.6 & 28.4 & 3.3 & 6.8 \\
\hline
\end{tabular}

Read the first column of data as "Percent of 15-19 year olds who received delivery assistance from a health professional."

If the respondent mentioned more than one person attending during delivery, only the most qualified person is considered in this tabulation.

Figures in parentheses are based on 25-50 unweighted cases.

${ }^{a}$ For their most recent birth in the five years preceding the survey

${ }^{\mathrm{b}}$ Other types include auxiliary midwife, relatives/friends of the woman, and servants 
Figure 16: Delivery Assistance Received by 15-24 Year Olds

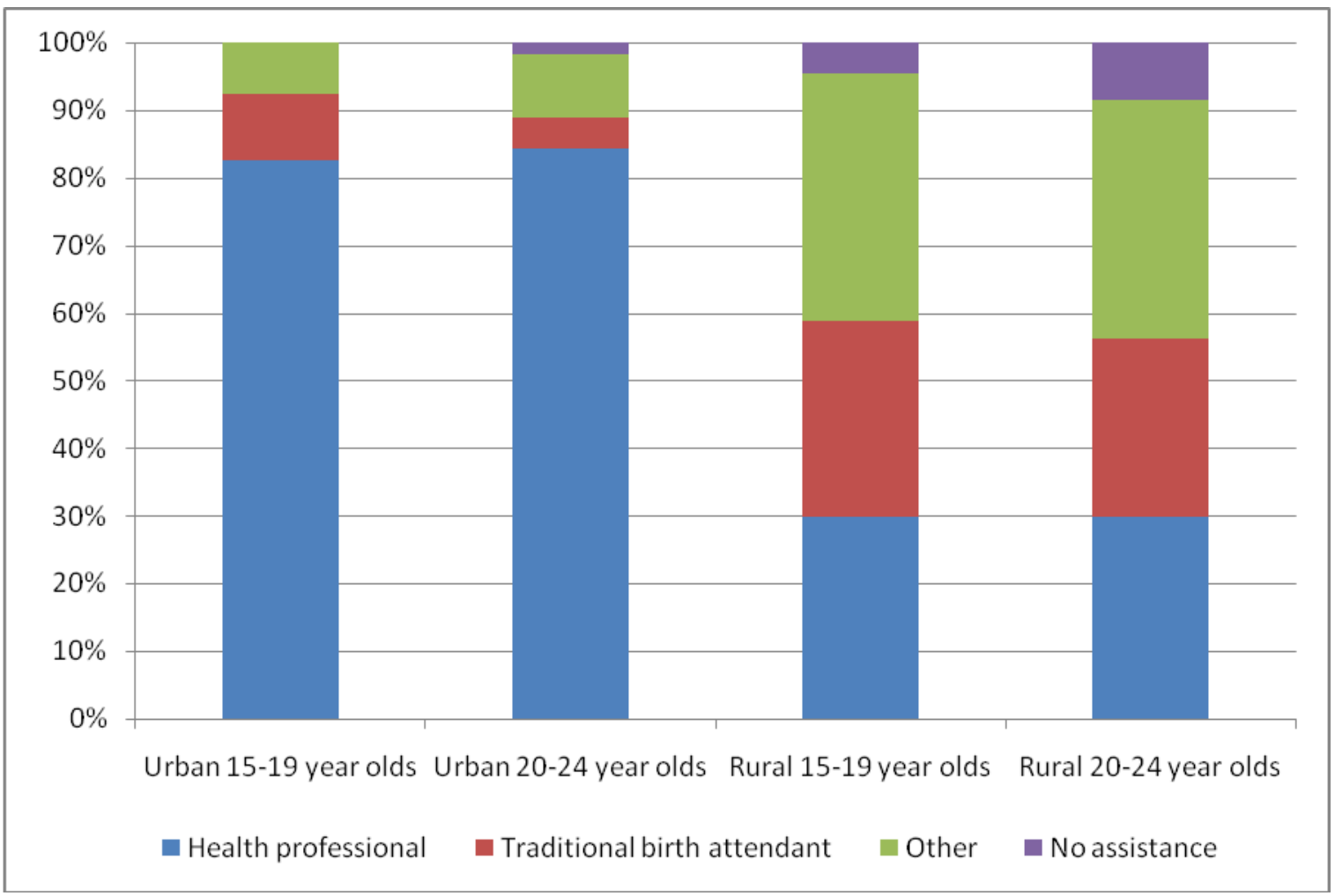




\section{V-Concluding Remarks}

The data in this report represent one of the critical components of any evidence-based strategy to reach the most vulnerable young people with targeted policies and programs. Given that the selected indicators cover a wide range of contexts and scenarios, policymakers and program designers from different sectors can begin to make the case for targeted investments directed at the needs of the most vulnerable, in particular girls. However, due to limitations in the DHS, the data are by no means exhaustive, nor do they cover all areas that may be necessary for local advocacy efforts. Country teams likely have access to additional sources of qualitative and quantitative data that may fill in the gaps as determined by the needs of these local actors. As a result, it would be of great value to this effort if the users of this data guide begin to contextualize the narrative by including country-specific observations based on experience and program examples while integrating additional sources of data. This effort will strengthen the overall effectiveness of this body of data by offering the local UN, government, and nongovernmental sectors a clearer understanding of how national priorities and mid-term goals are directly linked with the sub-national data that inform policy analysis, program design, and capacitybuilding efforts. 